\title{
Dole's Future:
}

\section{A Strategic Analysis}

\author{
Neil S. Siegel ${ }^{\dagger}$
}

\begin{abstract}
As the U.S. Supreme Court imposes federalism-based limits on congressional power under the Commerce Clause and Section Five of the Fourteenth Amendment, Congress may be tempted to turn to the conditional spending power in order to achieve goals that it cannot realize directly. In this article I address whether a danger exists, as some suggest, that such use of the Spending Clause would render the Court more likely to cut back on its scope, narrowing or overruling South Dakota v. Dole, 483 U.S. 203 (1987). Using doctrinal analysis and game theory, I conclude that Congress should proceed with some but not great caution. It may sensibly operate within the large universe of interventions that do not implicate the subject matter of previous decisions. Moreover, Congress may sensibly operate within the small universe of interventions that $d o$ implicate the subject matter of past rulings if the Court in these decisions indicated the permissibility of a Spending Clause substitute or if Congress deems its interest sufficiently important that it is worth taking the modest risk of causing the Court to revisit Dole.
\end{abstract}

\section{CONTENTS}

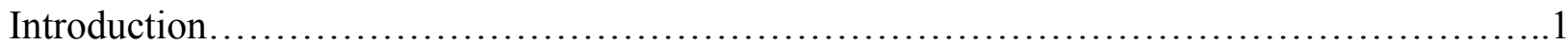

I. Getting Off the Dole ......................................................

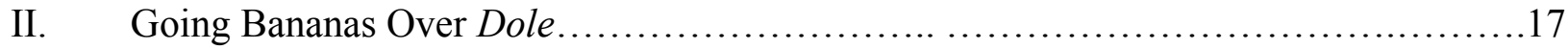

III. The Balancing Act.................................................... 30

Conclusion......................................................................... 44

${ }^{\dagger}$ Assistant Professor of Law and Political Science, Duke University School of Law. B.A. (Economics, Political Science) Duke University, 1994; M.A. (Economics) Duke University, 1995; J.D./Ph.D. (Jurisprudence \& Social Policy) University of California, Berkeley School of Law (Boalt Hall), 2001. For instructive feedback, I am grateful to Scott Baker, Stuart Benjamin, James Boyle, Erwin Chemerinsky, Jesse Choper, Robert Cooter, Michael Gerhardt, R. Craig Green, Michael Greve, Mitu Gulati, David Law, Margaret Lemos, Stefanie Lindquist, Elizabeth Magill, Ralf Michaels, Robert Post, H. Jefferson Powell, Jedediah Purdy, Tom Rowe, Pratik Shah, Steven Smith, Maxwell Stearns, Matthew Stephenson, Laurence Tribe, Adrian Vermeule, Barry Weingast, Jonathan Wiener, John Yoo, Lawrence Zelenak, and workshop participants at Berkeley, Duke, San Diego, and Temple. I thank Mark Sigmon and Chris Stiner for able research assistance. 


\section{INTRODUCTION}

Through repeated, blunt statements at oral argument in one of the more high-profile cases in recent Terms, Chief Justice Roberts may have revealed a lot about his view of the scope of Congress' conditional spending power. "[The Solomon Amendment] doesn't insist that you do anything," the Chief Justice told counsel for the coalition of law schools. "It says that, "If you want our money, you have to let our [military] recruiters on campus.",1 When counsel resisted this framing of the case, Chief Justice Roberts persisted: “[W]hat about South Dakota against Dole? South Dakota had a constitutional right, under the twenty-first amendment, to set whatever drinking age it wanted, and yet we upheld the Spending Clause condition that if they accepted Federal funds, they had to set their drinking age at 21."2 And when counsel tried to make the compelled-speech argument that students did not believe the schools' message of nondiscrimination because the recruiters were present, the Chief Justice interrupted: "The reason they don't believe you is because you're willing to take the money. What you're saying is, 'This is a message - [Laughter] — we believe in strongly, but we don't believe in it, to the tune of $\$ 100$ million.", Later in the argument, he reiterated that "you're perfectly free to do [what you want] if you don't take the money."4 Chief Justice Rehnquist could not have advanced the view that the greater power includes the lesser any more forcefully.

\footnotetext{
${ }^{1}$ Tr. of Oral Arg., Rumsfeld v. Forum for Academic and Institutional Rights, No. 04-1152, at 32 . The Solomon Amendment, 10 U.S.C. $\$ 1983($ b), requires law schools to allow military recruiters equal access to their facilities on pain of subjecting their universities to the loss of all federal funds. Most law schools denied the military access to their career-services offices because the federal law prohibiting homosexuals from serving in the military, 10 U.S.C. $\S 654$, violates the schools’ nondiscrimination policies.

${ }^{2} I d$. at 33. For discussion of Dole, see infra notes 8-10 and accompanying text.

${ }^{3} I d$. at $38-39$.

${ }^{4}$ Id. at 57.
} 
The Supreme Court declined to revisit its spending-power jurisprudence in Rumsfeld $v$.

$F A I R$, even in dicta. It instead ruled that "a funding condition cannot be unconstitutional if it could be constitutionally imposed directly." almost two decades, the Court has studiously avoided the doctrinal terrain of the spending power. ${ }^{6}$ The future, however, is less certain and the stakes are high. As Justices and commentators have recognized, ${ }^{7}$ the limits imposed by every major dimension of the Court's federalism jurisprudence - its decisions restricting federal power under the Commerce Clause, the Tenth Amendment, the Eleventh Amendment, and Section Five of the Fourteenth Amendment - can often be negotiated by Congress with a Spending Clause substitute under the doctrine set forth in South Dakota v. Dole. ${ }^{8}$

${ }^{5} 126$ S. Ct. 1297, 1307 (2006). Specifically, the Court held that it need not consider the conditional spending power because Congress could impose the equal-access requirement directly under its authority to "provide for the common Defence," to "raise and support Armies," and to "provide and maintain a Navy." $126 \mathrm{~S}$. Ct. at 1306-1307 (quoting U.S. Const. Art. I, §8, cls. 1, 12-13). Chief Justice Roberts did write for the Court, however, that "universities are free to decline the federal funds" if they do not wish to comply with the Solomon Amendment, $i d$. at 1306, perhaps suggesting that the early Roberts Court, like the Rehnquist Court, will not be inclined to find coercion even if so much money is at stake that no reasonable choice exists. See infra notes 147149 and accompanying text (discussing this issue).

${ }^{6}$ The Spending Clause (or General Welfare Clause) states in relevant part that "Congress shall have Power To lay and collect Taxes, Duties, Imposts and Excises, to pay the Debts and provide for the common Defence and general Welfare of the United States.” U.S. CONST. Art. 1, §8, cl. 1.

${ }^{7}$ See, e.g., Davis v. Monroe County Bd. of Educ., 526 U.S. 629, 654-55 (1999) (Kennedy, J., joined by Rehnquist, C.J. and Scalia and Thomas, JJ., dissenting) ("[T]he Spending Clause, if wielded without concern for the federal balance, has the potential to obliterate distinctions between national and local spheres of interest and power by permitting the Federal Government to set policy in the most sensitive areas of traditional state concern, areas which otherwise would lie outside its reach."); New York v. United States, 505 U.S. 144, 167 (1992) (noting the necessity of imposing limits on conditional federal spending under Dole because "otherwise, of course, the spending power could render academic the Constitution's other grants and limits of federal authority"); Jesse H. Choper, Taming Congress's Power Under the Commerce Clause: What Does the Near Future Portend?, 55 ARK. L. REV. 731,765 (2003) ("It seems plain that truly imposing substantive limits on Congress's regulatory reach, which the rhetoric of Lopez and Morrison describe, and thereby carving out areas of state sovereignty, rather than simply directing Congress to work its will in one way or another, will require the Court to address the Spending Clause."); Lynn A. Baker and Mitchell N. Berman, Getting off the Dole: Why the Court Should Abandon Its Spending Doctrine, and How a Too-Clever Congress Could Provoke It to Do So, 78 IND. L.J. 459, 460 (2003) (noting the "many commentators" who "have proposed that Congress should respond to the Rehnquist Court's states' rights decisions by using the spending power to circumvent those limitations on congressional power"); infra note 18 (citing more of the literature).

${ }^{8} 483$ U.S. 203 (1987). 
In Dole, the Court held that Congress may condition five percent of federal highway funds on the adoption by recipient states of a 21-year-old drinking age, even assuming (but not deciding) that the Twenty-First Amendment would prohibit Congress from imposing a national minimum drinking age directly. ${ }^{9}$ Chief Justice Rehnquist stressed for the majority that the condition imposed by Congress was "clearly stated," was "directly related to one of the main purposes for which highway funds are expended—safe interstate travel," and was not "so coercive as to pass the point at which pressure turns into compulsion." ${ }^{\prime 10}$

Dole allows Congress to accomplish indirectly much of what it cannot impose directly. For example, the Court has held that Congress did not lawfully employ its commerce power to prohibit gun possession in a school zone or to provide a private civil remedy for victims of gender-motivated violence. ${ }^{11}$ But under Dole, Congress may condition federal education or law enforcement funds on state enactments of such statutes. ${ }^{12}$ Similarly, the Court has concluded that Congress may not abrogate state sovereign immunity under the Commerce Clause ${ }^{13}$ or, oftentimes, under Section Five of the Fourteenth Amendment. ${ }^{14}$ Applying Dole, however, it

${ }^{9}$ Id. at $217-18$.

${ }^{10} I d$. at $208,211$.

${ }^{11}$ United States v. Lopez, 514 U.S. 549 (1995) (invalidating, for the first time since the New Deal, a federal statute regulating private conduct - the Gun Free School Zones Act of 1990 - as beyond the commerce power); United States v. Morrison, 529 U.S. 598 (2000) (holding that Congress lacked authority under either the Commerce Clause or $\S 5$ of the Fourteenth Amendment to enact a provision of the Violence Against Women Act of 1994 creating a private civil remedy for victims of gender-motivated violence).

${ }^{12}$ A critical difference between federal and state causes of action, however, is the relative burden placed on the dockets of federal and state courts. In addition, Congress may not require state compliance using the conditional spending power (states can escape the condition by declining the funds), and a Spending Clause incentive may be more costly for the federal government to use than a regulation enacted under the Commerce Clause or Section Five. A spending-power substitute, moreover, may sometimes be difficult to operationalize. See infra note 112.

${ }^{13}$ Seminole Tribe of Fla. v. Fla., 517 U.S. 44 (1996).

${ }^{14}$ See City of Boerne v. Flores, 521 U.S. 507 (1997) (holding that the Religious Freedom Restoration Act of 1993 was beyond the scope of §5); Florida Prepaid Postsecondary Education Expense Board v. College Savings Bank, 527 U.S. 627 (1999) (holding that the provisions of the Patent and Plant Variety Protection Remedy 
would seem that Congress may condition related federal funding on state waivers of immunity from suit. ${ }^{15}$ Finally, the Court has held that Congress may not order states to enact, to administer, or to enforce a federal regulatory program. ${ }^{16}$ But Dole allows Congress to condition grants of related federal funds on the agreement of states to perform any of these roles. ${ }^{17}$ As a doctrinal matter, all of this federal action appears permissible under Dole.

What is less clear among commentators is what Congress should do with its spending power in light of the present state of legal affairs. This question is particularly salient now, when the Rehnquist Court has become the Roberts Court and Justice Alito has succeeded Justice O’Connor. Defenders of robust federal power argue that Congress should use its conditional spending authority to pursue its regulatory goals indirectly where the Court has prohibited it from doing so directly. These critics of the Court's federalism jurisprudence view the leverage

Clarification Act of 1992 authorizing patent-infringement suits were beyond the scope of §5); Kimel v. Florida Board of Regents, 528 U.S. 62 (2000) (holding that the Age Discrimination in Employment Act of 1967 was beyond the scope of §5); Board of Trustees of University of Alabama v. Garrett, 531 U.S. 356 (2001) (holding that Title I of the Americans with Disabilities Act of 1990 (ADA) was beyond the scope of §5); Morrison, 529 U.S. at 598. But see Nevada Department of Human Resources v. Hibbs, 538 U.S. 721 (2003) (upholding the $\$ 5$ validity of the family-care leave provision of the Family and Medical Leave Act of 1993); Tennessee v. Lane, 124 S. Ct. 1978 (2004) (holding, as it applies to the class of cases implicating the fundamental right of access to the courts, that Title II of the ADA is valid §5 legislation); United States v. Georgia, 126 S. Ct. 877 (2006) (holding unanimously that insofar as Title II of the ADA creates a private cause of action for damages against states for unconstitutional conduct, Title II is valid under §5).

${ }^{15}$ See, e.g., infra note 146 (citing a relevant D.C. Circuit opinion by then-Judge Roberts).

${ }^{16}$ New York v. United States, 505 U.S. 144 (1992) (holding that the "take title" provision of the Low Level Radioactive Waste Policy Amendments Act of 1985, which required states either to regulate radioactive waste in accordance with Congress' requirements or to take title to the waste, constitutes unconstitutional compulsion and commandeering of state governments); Printz v. United States, 521 U. S. 898 (1997) (holding unconstitutional interim provisions of the Brady Handgun Violence Prevention Act that required state and local law enforcement officers to conduct background checks on prospective handgun purchasers).

${ }^{17}$ See infra note 57 (quoting New York, 505 U.S. at 166-67). 
provided by federal dollars as a potent tool left undisturbed by current law, one that Congress should employ extensively to pursue national objectives. ${ }^{18}$

"Not so fast," assert defenders of state authority. Professors Lynn Baker and Mitchell Berman of the University of Texas at Austin, for example, caution critics of the Court who argue that Congress should respond aggressively to the Court's federalism decisions by using the Spending Clause to "circumvent" them. ${ }^{19}$ Professors Baker and Berman submit "that the strategy urged by these commentators is a risky one that might provoke the Court to abandon Dole in favor of something much less hospitable to congressional power. ${ }^{, 20}$ They predict:

[N]ot even [Chief Justice] Rehnquist's pride of authorship would commit him to Dole if that test permits - as it very probably would — an unvarnished circumvention of one of the majority's decisions limiting congressional power. And if Dole goes, it is anybody's guess what may replace it. The replacement, however, might prove fatal to spending legislation that would have survived Dole, and might even prove fatal to legislation that already has survived Dole. In short, we believe that those who would urge Congress to exploit Dole to check the Rehnquist Court's states' rights revival might benefit from being more sensitive to the context-dependence of the creation of judicial doctrine. Put another way, we are urging a greater sensitivity to the need for strategic thinking. ${ }^{21}$

Professors Baker and Berman "rais[e] the specter ... of perverse consequences," insisting that "a too-clever Congress could push a partially reluctant Supreme Court to curb the most important congressional power that the Court's states' rights revival has thus far left untouched."22

\footnotetext{
${ }^{18}$ See, e.g., Mark Tushnet, Alarmism Versus Moderation in Responding to the Rehnquist Court, 78 IND. L.J. 47, 51-52 (2003) (counseling use of the Spending Clause in response to the Court's federalism decisions); Sylvia A. Law, In the Name of Federalism: The Supreme Court's Assault on Democracy and Civil Rights, 70 U. CIN. L. REV. 367, 391 (2002) ("Even though the Court has sharply constrained the power of Congress to act under the Commerce Clause and under [§5], many of the goals Congress seeks to achieve may still be pursued through the federal spending power.").

${ }^{19}$ Baker \& Berman, supra note 7.

${ }^{20} I d$. at 460 .

${ }^{21} I d$. at 461 .

${ }^{22} I d$.
} 


\section{Professors Baker and Berman anticipate the objection that a Court inclined to overrule}

Dole will do so regardless of what Congress does and thus that Congress should enact laws that it deems desirable without fear of an adverse judicial response. "The risk that ought to give Congress pause," they write, "is that in striking down the circumventionist legislation, the Court could reinvigorate Dole, or replace it, in ways that would prove fatal to noncircumventionist uses of the spending power that would have sailed through in the absence of any such change in judicial doctrine. ${ }^{, 23}$

I use doctrinal analysis and game theory to mediate this dispute among would-be congressional counselors. Employing readily comprehensible models, I scrutinize both theses by identifying their underlying assumptions, examining whether their conclusions follow from their assumptions, and evaluating the legal validity of these assumptions in light of the case law. Because the arguments on each side of this debate can be modeled as a strategic game, the proper resolution of the debate turns not on whether one displays "sensitivity to the need for strategic thinking, ${ }^{, 24}$ but rather on one's view of the content of the Court's preference orderings over the various possible outcomes in the strategic interaction.

${ }^{23} I d$. at 541. Because Professors Baker and Berman devote much of their article to explaining "why Dole should be abandoned," $i d$. at 469-85, the question arises whether they are engaging in strategic behavior. They argue that Congress should not use the spending power aggressively because doing so might cause the Court to cut back on its scope. But this outcome is exactly the result that they seek. So why do they urge congressional caution? They explain their "cautionary note," which "may seem to be against interest," as animated by the concern that "all depends upon what replaces Dole"; an "ill-conceived congressional provocation is apt to engender just the sort of illconceived judicial reaction from which sound constitutional doctrine is particularly unlikely to issue." Id. at 541 . They make a sensible point. But in evaluating their thesis, one should bear in mind that they would want Congress to take their advice even if the advice were decisively determined to be unsound. Professor Baker in particular is one of the leading proponents, if not the leading proponent, of strict judicial limits on the scope of the spending power. See, e.g., Lynn A. Baker, The Spending Power and the Federalist Revival, 4 CHAP. L. ReV. 195 (2001); Lynn A. Baker, Conditional Federal Spending after Lopez, 95 CoLUM. L. REV. 1911 (1995). Thus, her urging Congress to restrain itself in order to avoid an adverse judicial response must be understood in the context of her overall advocacy. Obviously, another way to achieve her goal would be for Congress to self-regulate by limiting its use of the spending power.

\footnotetext{
${ }^{24}$ Baker \& Berman, supra note 7, at 461.
} 
A strategic approach is particularly useful as a supplement to doctrinal analysis when the Court has recently undergone a transition and it is uncertain what changes the future may bring. ${ }^{25}$ As discussed below, ${ }^{26}$ different types of legal conservatives exist on federalism issues. Some view the Spending Clause as limited by the same federalism values that constrain Congress under the Commerce Clause and Section Five of the Fourteenth Amendment. Others view the spending power as different in kind, as concerning the power of Congress to control how federal dollars get spent. The sort of conservative jurists that Chief Justice Roberts and Justice Alito turn out to be may — or may not — decisively impact Dole's future and the optimal congressional strategy going forward. Strategic analysis, by tracing out the consequences of various assumptions about the relevant views of new Justices (or nominees), helps to clarify the stakes at a time of significant change on the Court.

While academic constitutional lawyers have not tended to adopt the strategic point of view in their work, ${ }^{27}$ political scientists and economists have been studying the congressionalCourt dynamic from this perspective for years. ${ }^{28}$ Legal academics have something to learn from social scientists in this regard, but the following inquiry will suggest that real potential exists for

${ }^{25}$ See, e.g., South Carolina v. Gathers, 490 U.S. 805 (1989) (Scalia, J., dissenting) (“'Overrulings of precedent rarely occur without a change in the Court's personnel.").

${ }^{26}$ See infra Part III.

${ }^{27}$ But see, e.g., William N. Eskridge, Jr. \& Philip P. Frickey, The Supreme Court 1993 Term-Foreward: Law as Equilibrium, 108 HARV. L. REV. 26 (1994); William N. Eskridge, Jr., Reneging on History? Playing the Court/Congress/President Civil Rights Game, 79 CAL. L. REV. 613 (1991).

${ }^{28}$ The literature is voluminous. For examples that themselves provide copious citations to the literature, see LeE EPSTEIn \& JACK KNIGHT, The ChOICES Justices MAKe (1998); James Rogers, Information and Judicial Review: A Signaling Game of Legislative-Judicial Interaction, 45 Am J. POL. SCI. 84 (2001); Georg Vanberg, Legislative-Judicial Relations: A Game-Theoretic Approach to Constitutional Review, 45 AM. J. POL. SCI. 346 (2001); Jeffrey A. Segal, Separation-of-Powers Games in the Positive Theory of Congress and Courts, 91 AM. POL. SCI. REV. 28 (1997); John Ferejohn \& Barry Weingast, A Positive Theory of Statutory Interpretation, 12 INT'L REV. L. \& ECON. 263 (1992). For a useful survey of the intellectual landscape, see Lee Epstein \& Jack Knight, Toward a Strategic Revolution in Judicial Politics: A Look Back, A Look Ahead, 53 POL. ReS. QuARTERLy 625 (2000). See also RoBert D. COOTER, THE STRATEGIC CONSTITUTION 211-39 (2000). 
intellectual reciprocity. Constitutional scholars are well positioned not only to use analytic tools developed by others, but also to sharpen these tools by discerning the meaning derived from close reading of constitutional texts. The solution to a model of the congressional-Court dynamic is compelled by the payoffs in the game. And these payoffs, if they are to be meaningful and not arbitrary or results-oriented, must be grounded in independent legal judgments about the views of the Justices on the subject matter at issue. Constitutional lawyers, not social scientists, are best situated to render such judgments.

Part I formalizes the argument that congressional use of the spending power in response to judicially imposed limits on other powers would cause the Court to narrow or overrule Dole. Part II questions the assumptions underlying the argument delineated in Part I, and offers a different model of the game between Congress and the Court based on assumptions implicitly held by critics of the Court. Part III explores the distinction (from the Court's perspective) between congressional "circumvention" of Court decisions and compliance with them through provision of a permissible legislative substitute. Part III then examines the current strategic situation, as best one can tell, based on the likely views of at least five current Justices. The evidence, while mixed and uncertain, is most supportive of a relatively robust view of congressional power under the Spending Clause. I conclude with some (unsolicited and uninsured) advice of my own for Congress.

\section{GetTing OfF the DOLE}

The key to understanding Supreme Court decisions limiting congressional power in the name of federalism lies in determining whether these rulings are best viewed as declaring that Congress cannot regulate an activity at all, or rather as announcing only that a particular law is 
beyond the scope of a specific power. If the Court is conveying in its federalism opinions that Congress should not try to regulate a particular activity at all, then "circumvention" (which carries obvious connotations of illegitimacy) occurs when Congress endeavors to do so through the Spending Clause after the Court invalidates Commerce Clause or Section Five legislation that would have advanced the same end. But if the Justices are saying just that certain regulatory conduct is not within the scope of the commerce power or Section Five, then using the spending power instead does not constitute "circumvention." Professors Baker and Berman advance the first interpretation. The term "substitution" describes the situation more neutrally. ${ }^{29}$

Are Professors Baker and Berman correct that "circumvention" of the Court's federalism decisions would cause the Justices to trim or overrule Dole, jeopardizing "noncircumventionist" uses of the spending power that otherwise would have remained secure? Answering this question requires predictions. In anticipating the Court's behavior - especially a reconstituted Court with new members whose views are uncertain ${ }^{30}$ - few bets are safe until the decisions come down. ${ }^{31}$ After the holdings, reasoning, and voting patterns in such recent cases as

${ }^{29}$ See infra Part III for discussion of the possible meaning(s) of "circumvention." In assessing Professors Baker and Berman's argument, I assume that a "circumvention" phenomenon exists. I note, however, that the term is definitionally ambiguous and conceptually problematic insofar as given government conduct either violates Supreme Court precedent or does not. If the former, it may not be circumvention; rather, it may just be a repetition of unlawful conduct. If the latter, it also may not be circumvention; it may just be lawful conduct. If the state of constitutional law is uncertain or indeterminate, as it often is, then it may be just as unclear or indeterminate whether a given government action is lawful or unlawful, but the action still may not constitute circumvention. In short, the term "circumvention" may be of limited usefulness, and it may tend to disappear when one is more precise about the rationale of the decision that allegedly has been "circumvented."

${ }^{30}$ Chief Justice Rehnquist was Dole's author and a member of the conservative majority who likely continued to view Dole as correctly decided. The possibility that Chief Justice Roberts may be a different type of conservative on federalism issues renders the future constitutionality of many instances of conditional federal spending uncertain. But see supra notes 1-4 and accompanying text (offering evidence that the views of the current Chief Justice are similar to those of his predecessor). For a discussion of what else is known about the relevant views of Chief Justice Roberts, see infra notes 144-149 and accompanying text. For an analysis suggesting that his views may not be decisive, at least as long as the Court's composition remains unchanged, see infra Part III. Justice Alito's views are largely (but not wholly) unknown. See infra notes 136-140, 150-151 and accompanying text.

${ }^{31}$ See, e.g., Robert C. Post, The Supreme Court, 2002 Term-Foreword: Fashioning the Legal Constitution: Culture, Courts, and Law, 117 HARV. L. REV. 4, 4 (2003) ("By any measure this last Term has proved 
Apprendi v. New Jersey, ${ }^{32}$ Bush v. Gore, ${ }^{33}$ Nevada Department of Human Resources v. Hibbs, ${ }^{34}$

Tennessee v. Lane, ${ }^{35}$ Hamdi v. Rumsfeld, ${ }^{36}$ Van Orden v. Perry, ${ }^{37}$ United States v. Georgia, ${ }^{38}$ and

remarkable. Confirming the endless capacity of the Court to astonish and surprise, the 2002 Term has shattered entrenched images of the Rehnquist Court.").

32530 U.S. 466 (2000) (holding that, other than a prior conviction, any fact that increases the penalty for a crime beyond the prescribed statutory maximum must be submitted to a jury and proved beyond a reasonable doubt). The Court's decisions in Apprendi and Blakely v. Washington, 542 U.S. 296 (2004), as well as the majority opinion finding a Sixth Amendment violation in United States v. Booker, 543 U.S. 220 (2005), reflect a seemingly strange 5-4 split, with Justices Stevens, Scalia, Souter, Thomas, and Ginsburg in the majority and Chief Justice Rehnquist and Justices O'Connor, Kennedy, and Breyer in dissent. Unclear before 2000, that 5-4 divide seems attributable to differences in methodology (i.e., legalism versus pragmatism) that were previously occluded by ideological differences evident in other areas.

${ }^{33} 531$ U.S. 98 (2000) (per curiam). So much has been said about this extraordinary case. I note only that many experts were confident that the Court would refuse effectively to decide the outcome of a Presidential election.

${ }^{34} 538$ U.S. 721 (2003). After City of Boerne, Florida Prepaid, Kimel, Garrett, and Morrison, see supra note 14, most experts were taken aback when the Court reversed course and upheld a federal statutory provision under Section 5. Moreover, the lineup in Hibbs caught many commentators by surprise: the vote was 6-3, with not only Justice O'Connor but also Chief Justice Rehnquist voting to uphold the statute. See, e.g., Vikram David Amar, The New "New Federalism": The Supreme Court in Hibbs (and Guillen), 6 GreEN BAG 2D 349, 349, 350 (2003).

${ }^{35} 541$ U.S. 509 (2004). It was a surprise to Section 5 experts that the Court applied City of Boerne's congruence-and-proportionality requirement not to Title II of the ADA as a whole, but only to the class of cases implicating the fundamental right of access to courts. In so holding, the Justices created confusion regarding how lower courts should handle future cases when private plaintiffs sue states for Title II violations. For example, why was the implicated class of cases in Lane "access to courts," as opposed to something narrower (such as physical access to court proceedings) or something broader (such as access to all government buildings and programs)? See Neil S. Siegel, A Theory In Search of a Court, and Itself: Judicial Minimalism at the Supreme Court Bar, 103 MicH. L. REV. 1951, 2005-06 (2005).

${ }^{36} 542$ U.S. 507, 529 (2004) (holding that although Congress had authorized the detention of a U.S. citizen seized in Afghanistan and held in the United States as an enemy combatant, due process demands that he be given a meaningful opportunity to contest the factual basis for his detention before a neutral decisionmaker). Surprises abound: Justice Breyer cast the decisive vote for the holding that Congress had authorized Yaser Esam Hamdi's detention; Justice Scalia dissented; and Justice Scalia went further in the direction of protecting civil liberties than did Justices Souter and Ginsburg. Compare id. at 539-53 (Souter, J., joined by Ginsburg, J., concurring in part, dissenting in part, and concurring in judgment) (concluding that Hamdi's detention was unlawful on statutory grounds), with id. at 553-79 (Scalia, J., joined by Stevens, J., dissenting) (concluding that Congress could not lawfully authorize Hamdi's detention without suspending the writ of habeas corpus).

${ }^{37} 125$ S. Ct. 2854 (2005). Justice Breyer - not Justice O’Connor — cast the decisive vote in Van Orden to uphold the Ten Commandments display on the Texas statehouse grounds. My Duke colleague Erwin Chemerinsky, who argued the case at the Court on behalf of Thomas Van Orden, was surprised both to lose 5-4 and to win Justice O'Connor's vote. See Erwin Chemerinsky, Why Justice Breyer Was Wrong in Van Orden v. Perry, 14 WM. \& MARY BILL RTS. J. 1, 2 (2006).

${ }^{38} 126$ S. Ct. 877 (2006). See supra note 14. The decision was unanimous, despite the apparent incompatibility of City of Boerne's "congruence and proportionality" test with the Georgia Court's decision to assess the Section 5 validity of Title II of the ADA only as applied to unconstitutional state conduct. See infra note 108. 
Central Virginia Community College v. Katz, ${ }^{39}$ one predicts the Court's conduct at one's peril.

Yet Congress must act one way or another in an uncertain legal world. Regarding the Baker-

Berman thesis in particular, moreover, game theory — which formalizes "strategic thinking" in part to identify "perverse consequences" $" 40$ — can be employed to test their reasoning.

Consider an extensive game that models the congressional-Court dynamic about which

Professors Baker and Berman write. ${ }^{41}$ Formal models, of course, simplify reality in order to explain and predict it. The "Baker-Berman Dole game" is no exception. ${ }^{42}$ Thus, while Congress has a continuous range of options at its disposal ${ }^{43}$ — from zero to limited to aggressive spendingpower responses to the Court's federalism decisions — the stylized Baker-Berman Dole game

${ }^{39} 126$ S. Ct. 990, 996 (2006). The Court held that Seminole Tribe, see supra note 13, did not affect bankruptcy proceedings, even though the Seminole Tribe majority and dissent agreed that it would.

${ }^{40}$ Baker \& Berman, supra note 7, at 461.

${ }^{41}$ An extensive game specifies the possible orders of events. Each player can consider her plan of action not only at the beginning of the game, but also whenever she must make a decision. MARTIN J. OSBORNE \& ARIEL Rubinstein, A Course In GAME TheORy 3, 89-90 (1994). See also Neil S. Siegel, Comment, State Sovereign Immunity and Stare Decisis: Solving the Prisoners' Dilemma within the Court, 89 CALIF. L. REV. 1165, 1176-77 (2001) (discussing games in extensive form).

${ }^{42}$ The game theory is just a helpful heuristic, an analytic tool. I of course do not endorse reformulating constitutional doctrine according to the normative criterion of economic efficiency, whether conceived as Pareto optimality or in cost-benefit terms. As has long been recognized, good reasons for skepticism exist regarding some of the normative stories told by economics, and the values implicated in the practice of constitutional adjudication, both instrumental and constitutive, are too pluralistic and potentially conflicting for any such reductionist exercise to succeed. See, e.g., Laurence H. Tribe, Constitutional Calculus: Equal Justice or Economic Efficiency?, 98 HARV. L. REV. 592 (1985) (arguing that "[t]he Constitution cannot be cabined in any calculus of costs and benefits," and that a cost-benefit approach is insensitive to distributional considerations and to the underlying conflicts about social values that constitutional law must address); Neil S. Siegel, Why the Eleventh Amendment Always Matters, Even When Transaction Costs are Zero: A Reply to Professor Farber, 18 Const. Comm. 177, 180-83 (2001) (refuting the claim that efficiency arguments should decide the legal debate over state sovereign immunity because the key question of authority is distributional in nature).

${ }^{43}$ Because Congress is not a monolithic entity, one might posit a situation in which Congress is composed of various groups, from liberal defenders of federal power to principled conservative federalists to results-oriented liberals and conservatives. One might also posit that certain groups engage in strategic behavior. For example, some members of Congress might vote in favor of a conditional federal spending statute in the hope that the Court would strike it down (contrary to the typical rational choice assumption that agents seek maximum power). This article makes no such distinctions among members because it would be wholly speculative to suggest that such camps persist within Congress on the question of how to employ the conditional spending power. Similarly, assumptions about strategic behavior of the kind just described lack a stable empirical referent. 
assumes just two alternatives: After the Court invalidates a statute enacted under the Commerce Clause or Section Five, Congress either uses its conditional spending power or declines to act. Similarly, the Court could respond by upholding the spending-power statute and reaffirming Dole, by striking it down and cutting Dole back minimally or extensively, or by invalidating the law and overruling Dole. The Baker-Berman Dole game, however, assumes only two responses: The Court either invalidates the law by cutting Dole back or sustains the law and leaves Dole alone. $^{44}$

So conceived, the Baker-Berman Dole game, in which the Court moves first, Congress moves second, and then the Court responds, has four possible outcomes: (A) the Court sustains the exercise of the commerce or Section Five power ("the regulation"45); (B) the Court invalidates the regulation and Congress declines to use the conditional spending power; $(\mathrm{C})$ the Court invalidates the regulation, Congress uses the conditional spending power, and the Court invalidates the spending-power substitute by trimming Dole; and (D) the Court invalidates the regulation, Congress uses the conditional spending power, and the Court sustains the spendingpower substitute, thus leaving Dole alone.

One can infer the preferences of Congress and the Court over these four possible outcomes. Congress would most prefer the outcome in which the Court sustains the regulation

\footnotetext{
${ }^{44}$ A game with three Court options - sustain Dole, cut Dole back, or overrule Dole — would be more realistic. I use the game with two options throughout this article because nothing is lost by omitting strictly dominated strategies. In other words, a Court bent on limiting the spending power likely would begin not by overruling Dole, but by tightening its generous requirements. See supra note 10 and accompanying text (discussing the relatedness and noncoercion requirements); see also infra note 151 (discussing the recent imposition of a stricter "clear notice" requirement). This is because the Justices usually would prefer not to overrule precedent if narrowing it would suffice to support the desired judgment. Chief Justice Roberts implicitly suggested as much in his May 21, 2006 commencement address at Georgetown University Law Center. He touted the virtues of narrow, incremental decision making to achieve consensus within the Court, opining that "[i]f it is not necessary to decide more to dispose of a case, in my view, it is necessary not to decide more." Available at http://www.law.georgetown.edu/webcast/eventDetail.cfm?eventID=146.

${ }^{45}$ I use the term "regulation" to characterize Commerce Clause and Section Five statutes in order to distinguish their mandatory nature from the incentives provided by conditional federal expenditures.
} 
(A). Congress would least prefer the outcome in which the Court invalidates the regulation, Congress offers a spending-power substitute, and the Court responds by invalidating the substitute and trimming Dole (C). In between these extremes, Congress prefers the scenario in which it uses the spending power and the Court sustains the law (D) to the situation in which Congress declines to use the spending power (B). Thus, Congress' preference ordering is (A) > (D) $>(B)>(C) .{ }^{46}$ Assigning its most-preferred outcome a payoff of 4, outcome (A) gets an ordinal payoff of 4 , which I designate as $(A)=4$. Similarly, $(D)=3,(B)=2$, and $(C)=1 .{ }^{47}$ The Court has different preferences over the four possible outcomes. ${ }^{48}$ For the argument advanced by Professors Baker and Berman to be valid, a majority of the Justices must most prefer the situation in which Congress does not attempt to use Dole in response to the invalidation of a regulation (B). ${ }^{49}$ The argument would be that the Court has had opportunities to overrule Dole but has declined to do so. ${ }^{50}$ At the same time, members of the conservative majority have stated that they do not want Congress to try to use Dole to undermine the

${ }^{46}$ The symbol ">" means "is preferred to."

${ }^{47}$ Ordinal payoffs, unlike cardinal payoffs, reveal only the order of preference, not relative intensities of preference. See, e.g., Daniel M. Hausman \& Michael S. McPherson, Economics, Rationality, and Ethics, in THE Philosophy of ECONOMics: An ANTHOlogy 252, 257 (Daniel M. Hausman ed., 2d ed. 1994).

${ }^{48}$ It is jurisprudentially coarse to view judges as having "preferences" in the way that consumers desire goods or that politicians pursue agendas. See, e.g., Don Herzog, As Many As Six Impossible Things Before Breakfast, 75 CALIF. L. REV. 609, 627 (1987) (observing that judges do not tend to render decisions according to their "first-order partisan commitments"). For an analysis of some problems with the conceptualization of the grounds of judicial decision as "preferences," see Neil S. Siegel, Comment, Sen and the Hart of Jurisprudence: A Critique of the Economic Analysis of Judicial Behavior, 87 CALIF. L. REv. 1581 (1999). One way to negotiate such difficulties is to conceive judges as rendering judgments about what the law requires, not as expressing personal preferences. See, e.g., Lewis A. Kornhauser \& Lawrence G. Sager, Unpacking the Court, 96 YALE L.J. 82, 88-89 (1986). In the present inquiry, this means conceiving the Court's numbers in the game trees as ordering the views of at least five Justices regarding what the Constitution demands.

${ }^{49}$ Like Congress, see supra note 43 , the Court is not a unitary actor. When the discussion and models in the text refer to "the Court," I am referencing the views of at least five Justices. When it is possible to arrange the relevant constitutional positions of the Justices along a single dimension, the view of the median Justice constitutes the view of the Court.

${ }^{50}$ See supra note 44; see also infra Part II. 
Constitution's commitment to federalism. ${ }^{51}$ The Court least prefers the outcome in which it sustains the regulation (A), because by hypothesis the Court is not prepared to let the regulation stand. In between these extremes, the Court prefers trimming Dole if Congress offers a spending-power substitution (C) to sustaining the substitution (D), because some of the Justices have warned that such a situation risks eviscerating the distinction between national and local spheres of authority. ${ }^{52}$ Thus, the Court's preference ordering, with associated payoffs, is $(\mathrm{B})=4$ $>(\mathrm{C})=3>(\mathrm{D})=2>(\mathrm{A})=1$.

The preference orderings of Congress and the Court can be combined in a game tree. The Court moves first, Congress moves second by using the Spending Clause (SC) or declining to act, and the game ends when the Court responds.

${ }^{51}$ See supra note 7. This reasoning reflects but also transcends the revealed-preference foundations of game theory. The argument embodies the assumption that a rational actor's choice behavior (here, judicial voting) reveals her preferences. But the argument also transcends behaviorism by parsing the communications of the Justices in their opinions. For a seminal critique of the behavioral foundations of economic theory, see Amartya Sen, Rational Fools: A Critique of the Behavioral Foundations of Economic Theory, 6 PHIL. \& PUB. AfF. 317, 336 (1977) (arguing that homo economicus is a "social moron," a "rational fool"); Amartya Sen, Behaviour and the Concept of Preference, 40 ECONOMICA 241, 258 (1973) (arguing that the "thrust of the revealed preference approach has been to undermine thinking as a method of self-knowledge and talking as a method of knowing about others"). For a critique of economic theories of judicial behavior inspired by the work of Amartya Sen and H.L.A. Hart, see Siegel, supra note 48.

${ }^{52}$ See supra note 7. Chief Justice Rehnquist's death and Justice O'Connor's retirement render the situation uncertain because we do not yet know how their replacements view Dole. See infra Part III. 


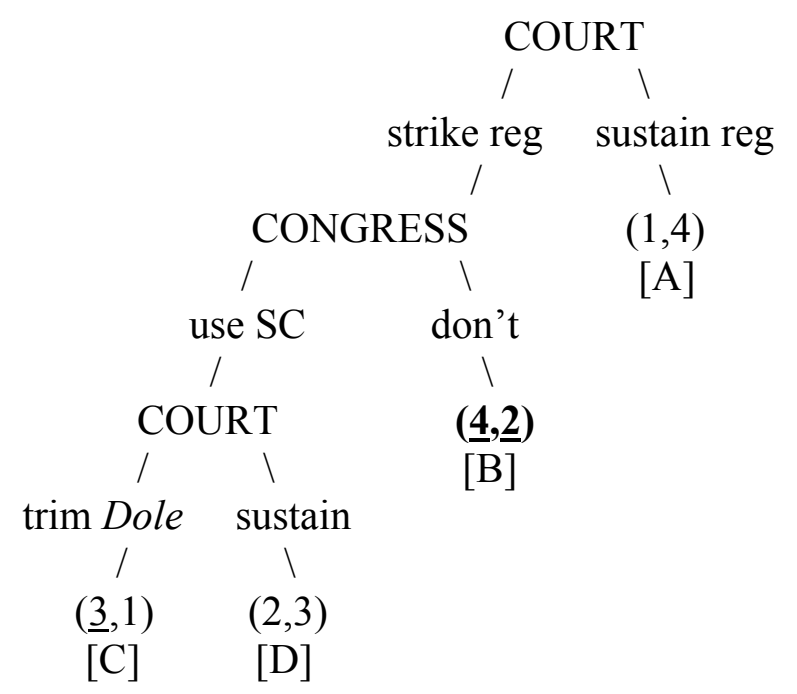

Figure One: The Baker-Berman Dole Game

The parentheses identify the respective payoffs for the Court and Congress - that is, $(\mathrm{X}, \mathrm{Y})$ signifies (Court's payoff, Congress' payoff). The bolded numbers highlight the solution to the game. The underlining is explained immediately below.

Because this is an extensive game, it can be solved using backwards induction. ${ }^{53}$ Starting at the end, the best replies of the Court and Congress are underlined. ${ }^{54}$ It is apparent from Figure One that if Congress responds to a regulatory invalidation by using its conditional spending power under Dole, the Court will respond by striking down the law and cutting Dole back. Congress is thus better off not attempting a spending-power substitute. Congress would prefer to “exploit" apparent "loopholes" in existing federalism doctrine (as Professors Baker and Berman would put it) in a non-strategic world — that is, a world in which the Court's behavior was not in

${ }^{53}$ Backwards induction counsels looking first at what the last-mover will do in the final round of a finitely repeated game. In the Baker-Berman Dole game, the last-mover is the Court. Backwards induction then advises turning to the next-to-last round, which is now effectively the last round. For a discussion of backwards induction, see OSBORNE \& RUBINSTEIN, supra note 41, at 99-100; Siegel, supra note 41, at 1178-1179.

${ }^{54}$ An actor's best reply to a choice of strategy by the other player(s) maximizes the actor's payoff. For a formal definition and discussion of best-reply or best-response functions, see OSBORNE \& RUBINSTEIN, supra note 41 , at 15. 
part responsive to the conduct of Congress. But this is not the world modeled by the Baker-

Berman Dole game. In this setting, one whose connection to the real legal world is explored in

Parts II and III, "context dependence" exists in "the creation of judicial doctrine."55 Thus,

Congress is best off not trying to "circumvent" the Court's decisions by using its conditional spending authority. ${ }^{56}$

By not enacting a spending-power substitute, Congress cannot achieve its second mostpreferred outcome and the corresponding payoff of 3 . Instead, it is left with its third-best result and an associated payoff of 2 . But at the same time, Congress avoids the worst possible outcome and a payoff of only 1. The game tracks Professors Baker and Berman's advice to advocates of congressional power: "If you think things are bad now, understand that they are not nearly as bad as they could be — and might become if you press the issue."

\section{GOING BANANAS OVER DOLE}

Critical to the Baker-Berman analysis in Part I is the suggestion that the Supreme Court would not want Congress to act through the Spending Clause to achieve results that the Court has not allowed Congress to pursue by using other constitutional grants of legislative power. But this assumption may not accurately reflect the preferences over outcomes of five current Justices.

${ }^{55}$ Baker \& Berman, supra note 7, at 461.

${ }^{56}$ The profile of strategies generating the $(4,2)$ outcome - that is, the Court invalidates the regulation and trims Dole in response to a spending-power substitute, while Congress declines to enact such a substitute - is not only a Nash equilibrium; it is also the unique subgame perfect equilibrium. The Nash equilibrium is the most basic solution concept in game theory. It is a profile of strategies in which no player has an incentive to change her strategy, given the strategies of the other players. Nash equilibria are thus stable in the sense that once achieved, no one has reason to deviate. OSBORNE \& RUBINSTEIN, supra note 41, at 14-15. In an extensive game, however, Nash equilibria are unsatisfactory because they ignore the sequential structure of the decision problems in the game, thus not distinguishing between equilibria that do and do not depend on noncredible threats. Because Nash equilibria do not account for the credibility of threats supporting equilibria, it is necessary to define a notion of equilibrium that captures this consideration. This solution concept, subgame perfection, eliminates Nash equilibria in which player threats are not credible by requiring that the actions prescribed by each player's equilibrium strategy be optimal, given the strategies of the other players, within each subgame. See id. at 97. 
In New York v. United States, for example, Justices Scalia, Kennedy, and Thomas joined Justice O'Connor's majority opinion, which stated that Congress could induce states to clean up nuclear wastes by placing strings on federal grants, even though Congress could not force states to do so directly:

This is not to say that Congress lacks the ability to encourage a State to regulate in a particular way, or that Congress may not hold out incentives to the States as a method of influencing a State's policy choices. Our cases have identified a variety of methods, short of outright coercion, by which Congress may urge a State to adopt a legislative program consistent with federal interests. ... [U]nder Congress' spending power, 'Congress may attach conditions on the receipt of federal funds.' South Dakota v. Dole, 483 U.S., at $206 \ldots{ }^{57}$

Judging from this textual evidence, the Court might not perceive a conditional federal grant after New York as congressional "circumvention"; on the contrary, the Court might view the grant as an instance in which Congress was exercising its constitutional authority appropriately. Indeed, it is somewhat perverse to view congressional action as "circumvention" — as attempting to "exploit" a "loophole" — when Congress follows to the letter the Court's instructions to legislate in one way and not another. A "permissible substitution" seems a more apt description. ${ }^{58}$

Other evidence from the U.S. Reports supports this position and cannot be dismissed. In Printz v. United States, ${ }^{59}$ Justice O'Connor wrote that "Congress is . . . free to amend the interim program to provide for its continuance on a contractual basis with the States if it wishes. ${ }^{.60}$ In

\footnotetext{
${ }^{57} 505$ U.S. at $166-67$.

${ }^{58}$ The distinction between substitution and circumvention shares normative similarities with the dichotomy in tax law between "tax avoidance" and "tax evasion." See, e.g., BORIS I. BITTKER, MARTIN J. MCMAHONE, JR. \& LAWRENCE A. ZELENAK, FEDERAL InCOME TAXATION OF INDIVIDUAls 1-27 (3d ed. 2002) (stating that "the former phrase denot[es] lawful modes of minimizing or avoiding tax liability; the latter, fraudulent behavior").

${ }^{59} 521$ U.S. 898 (1997).

${ }^{60} \mathrm{Id}$. at 936 (O’Connor, J., concurring).
} 
Alden v. Maine ${ }^{61}$ Justice Kennedy wrote for the Court and cited Dole in stating (albeit somewhat ambiguously) that, "subject to constitutional limitations, ... the Federal Government [does not] lack the authority or means to seek the States' voluntary consent to private suits." ${ }^{, 62}$

Moreover, several cases from the past few terms have implicated Spending Clause issues. In Pierce County v. Guillen ${ }^{63}$ the Court avoided a Spending Clause inquiry by holding unanimously that 23 U.S.C. $\$ 409$ constitutes a valid exercise of the commerce power. Section 409 protects information "compiled or collected" in connection with certain federal highway safety programs from being discovered or admitted in certain federal or state trials. Justice Thomas explained for the Court that "Congress adopted [the scheme] to assist state and local governments in reducing hazardous conditions in the Nation's channels of commerce," an effort that was impeded "by the States' reluctance to comply fully with the requirements of [the statute], as such compliance would make state and local governments easier targets for negligence actions by providing would-be plaintiffs a centralized location from which they could obtain much of the evidence necessary for such actions." ${ }^{, 64}$ According to the Court, "Congress could reasonably believe that adopting a measure eliminating an unforeseen side effect of the information-gathering requirement of [the law] would result in more diligent efforts to collect the relevant information, more candid discussions of hazardous locations, better informed decisionmaking, and, ultimately, greater safety on our Nation's roads.. ${ }^{, 65}$ The Court thus viewed the law as "aimed at improving safety in the channels of commerce and increasing protection for

\footnotetext{
${ }^{61} 527$ U.S. 706 (1999).

${ }^{62} I d$. at 755.

${ }^{63} 537$ U.S. 129 (2003).

${ }^{64}$ Id. at 147.

${ }^{65} \mathrm{Id}$.
} 
the instrumentalities of interstate commerce." ${ }^{\prime 66}$ This generous Commerce Clause analysis came as a surprise to many Court watchers. The Court's analysis in Guillen may suggest a disinclination to revisit Dole. ${ }^{67}$

Next, some commentators were concerned that the Court might cut back on the spending power in Sabri v. United States. ${ }^{68}$ At issue was the constitutionality of a federal criminal law, 18 U.S.C. $\S 666(a)(2)$, which prohibits bribing state and local officials of entities that receive at least $\$ 10,000$ in federal funds. The petitioner, a real estate developer, was indicted under the statute after offering bribes to a city councilman in the hopes of obtaining, among other things, city regulatory approvals. ${ }^{69}$

The Court could have sustained the statute on several relatively narrow grounds. Because Congress arguably could use the spending power to exceed the federalism-based limits imposed by the Court on the commerce power, one option was to hold only that $\S 666(a)(2)$ falls within congressional authority under the Spending and Necessary and Proper Clauses because bribery inherently implicates commercial activity. ${ }^{70}$ Another possibility was to limit the holding to

${ }^{66} I d$.

${ }^{67}$ See, e.g., Baker \& Berman, supra note 7, at 488 ("[T] case on dubious - and substantially underdeveloped - Commerce Clause grounds may indicate that the justices are ill-disposed to tinker with existing Spending Clause jurisprudence.”); Amar, supra note 34, at 355 ("This Commerce Clause focus was itself a somewhat surprising aspect of Guillen. As the case came up the appellate ladder, it seemed to center more on Congress' power to attach conditions to federal funding - the so-called 'spending clause' power. Indeed, many scholars thought that Guillen might be the first in a series of spending clause cases to come - a fifth line of cases, if you will - to round out the new federalism. Instead, the Court dodged the spending clause question, and upheld Congressional power under the Commerce Clause." (footnote omitted)).

${ }^{68} 541$ U.S. 600 (2004).

${ }^{69} I d$. at $602-603$.

${ }^{70}$ The Supreme Court, 2003 Term-Leading Cases, 118 HARV. L. REV. 248, 382-83 (2004) (noting the narrower option proposed in the text while articulating Sabri's breathtaking implications for the values animating the Court's federalism jurisprudence). 
bribery of officials in a position to impact how federal funds are spent. ${ }^{71}$ Or the Court could have upheld the statute under its existing Commerce Clause jurisprudence. ${ }^{72}$ Like the federal regulation of local "loan sharking" activities upheld in Perez v. United States,${ }^{73}$ bribery of public officials has a substantial effect on interstate commerce in the aggregate. The commercial nature of bribery also brings $§ 666(a)(2)$ within the commerce power under United States v. Lopez ${ }^{74}$ and United States v. Morrison. ${ }^{75}$

Instead of choosing any of these paths, the Court underscored the breadth of federal power to legislate pursuant to the spending and necessary and proper hooks, holding that Congress may enact criminal statutes as long as the prohibitions they contain have some rational connection to protecting the purposes of federal funding. ${ }^{76}$ Stressing that "[m]oney is fungible" ${ }^{\text {"77 }}$ and that the statute addresses bribery problems at the source "by rational means" $" 78$ is not the work of a Court concerned about the scope of the spending power. Under the Court's reasoning, anyone relevantly associated with any official of any entity receiving a certain threshold amount of federal funds can be brought within the purview of federal criminal laws.

${ }^{71} I d$. (rejecting the proposal in the text as a plausible interpretation of the Court's opinion).

${ }^{72}$ Justice Thomas relied on the commerce power to uphold the statute. He took exception to "the scope the Court gives to the Necessary and Proper Clause as applied to Congress' authority to spend." 124 S. Ct. at 1949 (Thomas, J., concurring in judgment).

${ }^{73} 402$ U.S. 146, 151-55 (1971).

${ }^{74} 514$ U.S. 549, 561 (1995) (stressing that the criminal law at issue "by its terms has nothing to do with 'commerce' or any sort of economic enterprise, however broadly one might define those terms").

${ }^{75} 529$ U.S. 598, 610 (2000) (emphasizing "the role that the economic nature of the regulated activity plays in our Commerce Clause analysis").

\footnotetext{
${ }^{76}$ Sabri, 541 U.S. at $605-608$.

${ }^{77} I d$. at 606 .

${ }^{78} I d$. at 605 .
} 
To be clear, Sabri was not a conditional federal spending case; it concerned the scope of the spending power, not the separate question of limits on use of the conditional spending power. Legislating directly to protect the integrity of federal funds is not the same thing as encouraging states to act in a certain way by tempting them with federal funds. But a Court bent on revisiting Dole likely would have been loath to adopt such a broad construction of the spending and necessary and proper powers in Sabri. Yet this is what every Justice except Thomas did. ${ }^{79}$

Turning from federal criminal law to statutes aimed at protecting the free exercise of religion, the Religious Land Use and Institutionalized Persons Act of 2000 ("RLUIPA") ${ }^{80}$ is a federal civil rights law that, in certain settings, protects the free exercise of religion and prohibits religious discrimination. The spending power supports the institutionalized-persons provisions of the statute, ${ }^{81}$ which provide more protection to the religious practices of prisoners in state and local institutions than they receive under existing constitutional doctrine. ${ }^{82}$ RLUIPA has been described informally as "the child of RFRA" because both statutes might be viewed as congressional responses to the Court's limited conception of the Constitution's protection of free exercise. ${ }^{83}$ Whether the Justices will entertain a Spending Clause challenge to RLUIPA in the

${ }^{79}$ See supra note 72 (describing Justice Thomas' view of the case).

${ }^{80} 42$ U.S.C. $\$ 2000$ cc et seq.

${ }^{81}$ Congress mandated compliance whenever "the substantial burden [on religion] is imposed in a program or activity that receives Federal financial assistance.” 42 U.S.C. $\$ 2000 \mathrm{cc}-1(\mathrm{~b})(1)$.

${ }^{82}$ Specifically, Section 3(a) specifies that "[n]o government shall impose a substantial burden on the religious exercise of a person residing in or confined to an institution," unless the burden "is in furtherance of a compelling governmental interest" and "is the least restrictive means" of advancing this interest. 42 U.S.C. $\$ 2000 \mathrm{cc}-1$ (a). Under the Court's holding in Employment Division v. Smith, 494 U.S. 872 (1990), by contrast, neutral laws of general applicability that incidentally burden religious practice do not violate the Free Exercise Clause.

${ }^{83}$ In City of Boerne v. Flores, 521 U.S. 507 (1997), the Court rejected Congress' attempt effectively to undo Employment Division v. Smith. The Court in City of Boerne held that the Religious Freedom Restoration Act of 1993 ("RFRA"), 42 U.S.C. §2000bb et seq., exceeded the $\$ 5$ power. In comparison to RLUIPA, RFRA imposes a broader obligation on the federal government to justify substantial burdens on religion imposed by any federal activity — not just zoning or institutionalization. Both laws reflect the strategic reality that in some areas, a 
future remains to be seen, as does the question whether the Court will view RLUIPA differently from RFRA because RLUIPA is based on a spending-power condition, not a Section Five-power prohibition. The only two circuits that have decided whether RLUIPA was validly enacted under the Spending Clause - the Seventh and the Ninth — have upheld the law in light of Dole. ${ }^{84}$

During the October 2004 Term, the Court rejected an Establishment Clause challenge to RLUIPA. ${ }^{85}$ Writing for a unanimous Court, Justice Ginsburg expressly declined to reach the Spending Clause issue because the question had not been addressed by the court of appeals. ${ }^{86}$ It may be revealing, however, that she contrasted RFRA, which "notably lacked a Commerce Clause underpinning or a Spending Clause limitation to recipients of federal funds," with RLUIPA, which is "[1]ess sweeping than RFRA, and invok[es] federal authority under the Spending and Commerce Clauses." ${ }^{87}$ Justice Thomas, by contrast, wrote that RLUIPA "may well exceed Congress' authority under ... the Spending Clause." ${ }^{88}$ Yet as in Sabri, no one joined his opinion.

"conservative" Congress may disagree with a "conservative" Court, thereby generating a conflict over the spending power. Congress passed RFRA and RLUIPA overwhelmingly, with many conservative sponsors. Crime legislation is another likely point of contention between certain conservatives in Congress and certain conservatives on the Court. See, e.g., Lopez, supra notes 11, 74.

${ }^{84}$ Charles v. Verhagen, 348 F.3d 601, 606-10 (7th Cir. 2003); Mayweathers v. Newland, 314 F.3d 1062, 1066-67 (9th Cir. 2002), cert. denied, 540 U.S. 815 (2003). The absence of a circuit conflict (let alone a mature split) likely accounts for the several denials of certiorari on the Spending Clause question. See, e.g., Bass v. Madison, 125 S. Ct. 2536 (2005); Alameida v. Mayweathers, 540 U.S. 815 (2003).

${ }^{85}$ See Cutter v. Wilkinson, 544 U.S. 709 (2005).

${ }^{86}$ Id. at 719 , n.7.

${ }^{87} I d$. at 715 .

${ }^{88} I d$. at 727, n. 2 (Thomas, J., concurring) (citing his Sabri concurrence in the judgment); see also id. at 2128-29 (Thomas, J. concurring) ("RLUIPA may well exceed the spending power"). 
All of these data points are most reasonably interpreted as suggesting that the Court has not wanted to revisit the conditional spending power. ${ }^{89}$ More generally, the submission that the Court's federalism jurisprudence is about substance, not form - about federalist substantive values, ${ }^{90}$ not legislative drafting technique ${ }^{91}$ — oversimplifies a complicated, internally conflicted jurisprudence. United States $v$. Lopez, ${ }^{92}$ for example, is widely believed to sit in tension with Wickard v. Filburn, ${ }^{93}$ even if they can be reconciled. Yet the Lopez Court reaffirmed Wickard, and the Court made clear in Gonzales v. Raich ${ }^{94}$ that Lopez means what it says in this regard.

${ }^{89}$ For an analysis of where the Roberts Court likely stands on Dole, see infra Part III.

${ }^{90}$ For discussions of the various values that federalism might be thought to serve, see STEPHEN G. BREYER, ACTIVE LIBERTY: INTERPRETING OUR DEMOCRATIC CONSTITUTION 56-59 (2005); CoOTER, supra note 28, at 10148; David Shapiro, Federalism: A Dialogue (1995); Neil S. Siegel, International Delegations and the Values of Federalism, 70 L. \& CONTEMP. PROB. (forthcoming 2007); Neil S. Siegel, Commandeering and Its Alternatives: A Federalism Perspective, 59 VAND. L. REV. 1629 (2006); Edward L. Rubin \& Malcolm Feeley, Federalism: Some Notes on a National Neurosis, 41 U.C.L.A. L. REV. 903 (1994); Andrzej Rapaczynski, From Sovereignty to Process: The Jurisprudence of Federalism after Garcia, 1985 SUP. CT. REV. 341. For an overview of the normative federalism debate in American constitutional law and citations to the literature, see ERWIN CHEMERINSKY, CONSTitutional LAW 109-12 (2d ed. 2005).

${ }^{91}$ See, e.g., Baker \& Berman, supra note 7, at 506-07 (“The States' Rights Five have made clear in a variety of contexts that they will not allow their substantive doctrines to be evaded by niceties of pleading. Surely they will be just as committed to ensuring that federalism does not become an ingenious exercise in legislative drafting." (footnote omitted)). But see Gonzales v. Raich, 125 S. Ct. 2195 (2005) (O'Connor, J., dissenting) (stating that if the six-Justice majority "is right, then Lopez stands for nothing more than a drafting guide"). Justice O'Connor's point concerns a different kind of drafting: she is worried about permitting Congress to draft its way out of commerce-related limits while still legislating under the Commerce Clause, not about letting Congress do the same thing under a different power. But both situations implicate an alleged tension between federalism values and drafting form.

${ }^{92}$ See supra notes 11, 74 and accompanying text.

93317 U.S. 111 (1942) (holding that the commerce power extends to purely intrastate activity that does not produce goods for sale if Congress rationally concludes that failure to regulate that class of activity would undercut regulation of the interstate market in the commodity produced by the activity).

${ }^{94} 125$ S. Ct. 2195, 2205-09 (2005) (relying in significant part upon Wickard in holding that the Commerce Clause authorizes Congress to prohibit the local cultivation and use of marijuana in states allowing such activity). 
Even when Lopez is considered in isolation, the decision illustrates my point nicely. Few would dispute that reenacting the law with a jurisdictional element is constitutional, ${ }^{95}$ and the Court has apparently not been eager to revisit the statute. Yet the present law undermines the very federalism values that the Court deemed so important in Lopez itself.

It is not obvious why the federal government may regulate home-grown wheat and marijuana, but not gun possession in schools (absent a jurisdictional element) or widespread private violence against women, even in the face of voluminous congressional evidence of significant effects on interstate commerce. ${ }^{96}$ If part of the answer turns on whether the failure to regulate would undermine a valid federal regulatory program, Justice O'Connor's objection that such claims were plausible but unproven in Raich has force. ${ }^{97}$ If part of the answer concerns the status of criminal-law enforcement as a traditional, sensitive subject of state concern, then one must distinguish Raich, account for the Court's apparent indifference to the numerous certiorari petitions challenging the constitutionality of federal gun-possession statutes, ${ }^{98}$ and explain why the Court did not pause before authorizing robust criminal regulatory power under the Spending Clause in Sabri. ${ }^{99}$ There do not appear to be easy answers to these questions, among others.

${ }^{95}$ Congress redrafted the statute and included a jurisdictional element to address the Court's Commerce Clause objections. See 18 U.S.C. $\$ 922(q)(2)(A)$ (limiting the statute's coverage to "a firearm that has moved in or that otherwise affects interstate or foreign commerce").

${ }^{96}$ See Morrison, 529 U.S. at 628-29 (Souter, J., dissenting) (“One obvious difference from [Lopez] is the mountain of data assembled by Congress, here showing the effects of violence against women on interstate commerce.").

${ }^{97}$ Raich, 125 S. Ct. at 2228-29 (O’Connor, J., dissenting).

98 See, e.g., United States v. Rybar, 103 F.3d 273 (3rd Cir. 1996) (holding that the Commerce Clause supports 18 U.S.C. $\S 922(0)$, which makes it "unlawful for any person to transfer or possess a machinegun"), cert. denied, Rybar v. United States, 522 U.S. 807 (1997). The Rybar case was widely discussed during Justice Alito's confirmation hearings because then-Judge Alito dissented from the panel majority opinion.

${ }^{99}$ See supra notes 68-79 and accompanying text (discussing Sabri). 
It is also puzzling why the same Justices who wrote passionately about the virtues of federalism often seemed somewhat tone deaf to the implications of broad federal preemption for the vindication of a substantive vision of state autonomy. The five Justices in the "states' rights" majority in cases involving the scope of congressional power under the Commerce Clause ${ }^{100}$ or Section Five of the Fourteenth Amendment ${ }^{101}$ were often the most likely to hold state law preempted. ${ }^{102}$ Professor Ernest Young has made this point repeatedly, ${ }^{103}$ as have other commentators of diverse ideological commitments. ${ }^{104}$ The Justices, however, have not addressed the apparent tension. ${ }^{105}$

\footnotetext{
${ }^{100}$ See supra note 11 (citing the relevant decisions).

${ }^{101}$ See supra note 14 (citing the relevant decisions).

102 See Richard H. Fallon, Jr., The "Conservative” Paths of the Rehnquist Court's Federalism Decisions,
} 69 U. CHI. L. REV. 429, 462 (2002) (observing that the Rehnquist Court held in favor of federal preemption in almost two-thirds of the then thirty-five preemption cases decided since Justice Thomas joined the Court); Daniel J. Meltzer, The Supreme Court's Judicial Passivity, 2002 SuP. CT. REV. 343, 369-70 (studying the Rehnquist Court's voting alignments in eight nonunanimous preemption cases decided during the October 1999-2001 Terms; noting that "Justice Scalia voted to preempt in all eight, the Chief Justice and Justices O'Connor and Kennedy in seven each, and Justice Thomas in six"; and further observing that "in those same eight cases, Justices Souter, Ginsburg, and Breyer each voted to preempt only twice and Justice Stevens never voted to preempt").

${ }^{103}$ See, e.g., Ernest A. Young, Two Cheers for Process Federalism, 46 VILL. L. REV. 1349, 1377-84 (2001) (observing that the Rehnquist Court's allegedly state-rights majority often votes against the states in preemption cases). See also, e.g., Ernest A. Young, The Rehnquist Court's Two Federalisms, 83 TEX. L. REV. 1, 23 (2004) (distinguishing "sovereignty" in the sense of legal unaccountability for violations of federal law from "autonomy" defined as the ability of states to govern, and submitting that "[ $t]$ he Court's preference for sovereignty over autonomy is the most obvious hallmark of the "federalist revival"').

${ }^{104}$ See, e.g., Erwin Chemerinsky, Empowering States When It Matters: A Different Approach to Preemption, 69 BROOK. L. REV. 1313 (2004) (criticizing the Rehnquist Court's preemption decisions for broadly interpreting federal law in favor of commercial interests and at the expense of progressive state regulatory measures); Calvin Massey, Federalism and the Rehnquist Court, 53 HASTINGS L.J. 431, 508 (2002) ("It is hard to understand why Justices who are so aware of the values of federalism in Lopez, Morrison, or Garrett exhibit such blindness to those values when presented with a preemption case."); Fallon, supra note 102, at 471-72; Meltzer, supra note 102, at 362-78. But see Michael S. Greve \& Jonathan Klick, Preemption in the Rehnquist Court: A Preliminary Empirical Assessment, 14 SuP. CT. ECON. REv. 43, 46 (2006) (questioning "the widespread impression of a sharp discontinuity between the Rehnquist Court's 'pro-state' federalism decisions and its 'nationalist' preemption decisions").

${ }^{105}$ For an analysis of the Court's indifference to the impact of broad federal preemption on state regulatory control in the context of commandeering context, see generally Siegel, supra note 90. 
Reasonable people disagree about what to make of the Court's Commerce Clause jurisprudence. But it seems evident from the case law that the Rehnquist Court did not include five genuine "States' Rights" advocates. ${ }^{106}$ Justice Thomas is arguably such a jurist, but Justices Scalia and Kennedy care greatly about both federalism and robust national regulatory power. ${ }^{107}$ The Rehnquist Court simply struggled to validate both in an internally consistent and nonconclusory fashion. ${ }^{108}$ This difficulty is unsurprising in light of the mixed signals sent by the Constitution that the Justices are charged with interpreting. ${ }^{109}$

Moreover, Justices who care deeply about federalism might not resist uses of the spending power that permit Congress to reach, by means of a conditional spending grant, results that the Court has placed off limits under the Commerce Clause or Section Five. The Court may perceive a substantive difference between the commerce power and the spending power; the two clauses may speak to different questions. The commerce power may implicate federalism issues primarily, while the Spending Clause may be concerned principally with the authority of Congress to control how its money gets spent (assuming that Congress meets the relatedness requirement $^{110}$ ). Chief Justice Rehnquist, for example, tended to gravitate towards arguments assuming that the greater power includes the lesser, ${ }^{111}$ and most Justices may believe that

${ }^{106}$ For an analysis of the Roberts Court, see infra Part III.

107 See infra Part III.

108 The Court's Section 5 jurisprudence suffers from similar analytic problems. See, e.g., Amar, supra note 34, at 350-54 (identifying inconsistencies between Hibbs and Garrett); see also supra note 35 (noting problems generated by Lane); notes 14 and 38 (noting that the Court's approach in United States v. Georgia appears incompatible with the analysis employed in previous cases such as Florida Prepaid).

${ }^{109}$ For an insightful analysis of this point just after Lopez came down, see Robert F. Nagel, The Future of Federalism, 46 CASE W. RES. L. REV. 643 (1996).

${ }^{110}$ See supra note 10 and accompanying text (discussing the relatedness requirement).

111 See supra notes 8-10 and accompanying text. See also, e.g., Posadas de Puerto Rico Associates v. Tourism Co. of Puerto Rico, 478 U.S. 328, 345-46 (1986) ("In our view, the greater power to completely ban casino 
conditional grants are neither as coercive as regulations, ${ }^{112}$ nor as offensive to state sovereign dignity. ${ }^{113}$ It is therefore misleading to characterize the spending-power debate among Justices and commentators as turning on form versus substance. ${ }^{114}$ Distinct kinds of substance are in play. $^{115}$

For all of these reasons - specific Rehnquist Court decisions, an internally conflicted jurisprudence, and substantive differences between the commerce and spending powers — the assumptions about the Court's preferences reflected in the Baker-Berman Dole game may be incorrect. The strategic situation changes dramatically if we leave the preferences of Congress in this game undisturbed but alter the Court's to reflect Justice O'Connor's preference revelation in New York, ${ }^{116}$ which at least five current Justices may share. ${ }^{117}$ I call the following model of this

gambling necessarily includes the lesser power to ban advertising of casino gambling ....”). Chief Justice Roberts appears to share his predecessor's view. See supra notes 1-4, 144-149 and accompanying text.

${ }^{112}$ As noted earlier, see supra note 12 , the incentives provided by use of the spending power constitute an imperfect substitute for the obligations backed by sanctions imposed by use of the Commerce Clause or Section Five. It would be interesting from a policy perspective, and potentially relevant in constitutional litigation, to learn more about the relative efficacy in various settings of regulations versus conditional subsidies. Much would depend on the ability to operationalize a Spending Clause substitute. Much might also depend on the amount of the subsidy. See, e.g., Denis Binder, The Spending Clause as a Positive Source of Environmental Protection: A Primer, 4 CHAP. L. REV. 147, 160-61 (2001) ) ("As a practical matter, states will not reject large sums of money offered by Congress unless the conditions are unduly repressive. ... South Dakota, Nevada, and Virginia sued to invalidate conditions attached to the receipt of federal highway trust funds. However, upon losing their suits, the states promptly complied with the conditions. Federal funds trumped state principles." (footnotes omitted)).

${ }^{113}$ The Court's state sovereign immunity and Tenth Amendment decisions exhibit concern to disable Congress from offending the dignity of states as sovereigns in a federal system. See supra notes 13-14 and accompanying text (citing the relevant cases). See also Elizabeth Anderson and Richard H. Pildes, Expressive Theories of Law: A General Restatement, 148 U. PENN. L. ReV. 1503, 1559 (2000) (suggesting that New York and Printz may be animated by concern that commandeering expresses disrespect for states); Jonathan H. Adler, Judicial Federalism and the Future of Federal Environmental Regulation, 90 IowA L. REV. 377, 397 (2005) ("[T] he Court has invalidated federal actions that impede upon, or affront the 'dignity' of, states qua states.").

${ }^{114}$ See, e.g., supra note 91 and accompanying text (discussing this claim).

115 The Court's views of state sovereign dignity and potential federal coercion may be related. Just as dignitary concerns require treating states as "grown ups," so part of being a grown up entails taking personal responsibility and saying "no" even in the face of great temptation. If it makes scant sense to personify states in one of these ways, then it probably makes little sense to personify states in the other as well.

${ }^{116}$ See supra note 57 and accompanying text. 
scenario the "Go-Bananas-Over-Dole game," because it suggests that critics of the Court can sensibly counsel widespread congressional use of Dole to advance federal interests regardless of whether the Court has held the targeted activity to be beyond the scope of the Commerce Clause or Section Five. In this game, the Court is indifferent between congressional inaction and action under the Spending Clause (SC) in response to Commerce Clause or Section Five invalidations. I therefore assign both outcomes an ordinal payoff of 3, and I assign a payoff of 2 to the outcome in which the Court trims Dole in response to congressional use of the spending power.

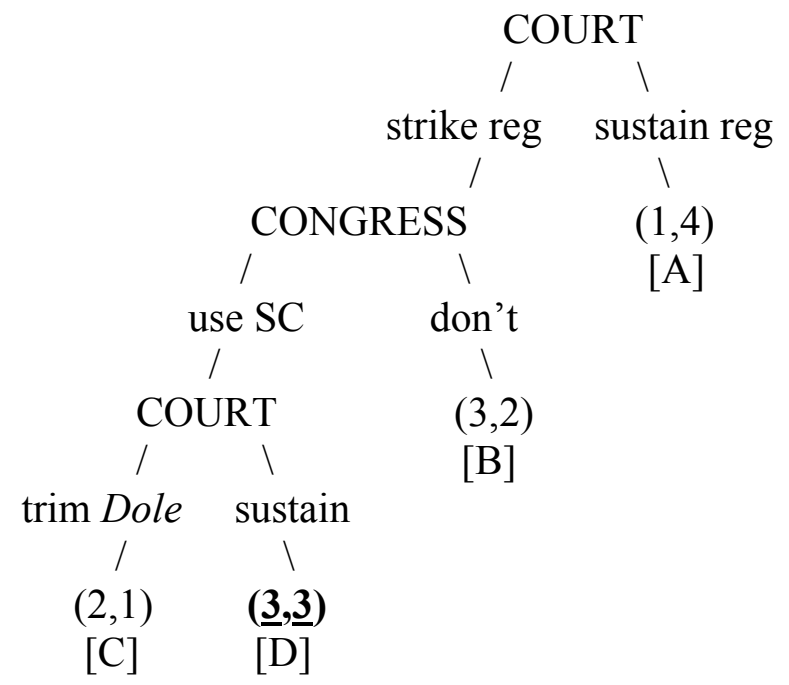

Figure Two: The Go-Bananas-Over-Dole Game ${ }^{118}$

Here, Congress may use the spending power aggressively and secure its second highest payoff because the Court will respond by sustaining the condition on federal funding and leaving Dole alone. Thus, the different conclusions reached by opponents and proponents of aggressive congressional use of the Spending Clause are not explained by the assertion that only Professors

\footnotetext{
${ }^{117}$ In addition to Justices Stevens, Souter, Ginsburg, and Breyer, Justice Scalia joined the majority opinion in Dole, and Justices Scalia and Kennedy joined Justice O'Connor's opinion in New York. The above discussions of Guillen, Sabri, and Cutter also support this conclusion. For an analysis of the current situation, see infra Part III.

${ }^{118}$ Recall that $(\mathrm{X}, \mathrm{Y})$ conveys the payoffs of the Court and Congress, respectively; the underlining identifies the Court's best reply to a move by Congress; and the bold-faced type indicates the solution.
} 
Baker and Berman exhibit "sensitivity to the need for strategic thinking.", ${ }^{119}$ Rather, each side in this debate is making outcome-determinative assumptions — grounded in doctrinal analysis about the Court's preferences over outcomes that may or may not be correct in many spendingpower cases. $^{120}$

\section{ThE BALANCING ACT}

The foregoing models diverge in a critical way. The first, but not the second, assumes that the Court views use of the conditional spending power in response to a Commerce Clause or Section Five invalidation as "circumvention" and thus impermissible. This term is loaded, and its meaning needs to be specified precisely. ${ }^{121}$ The Court may have one of several views when it strikes down a law as exceeding the scope of the Commerce Clause or Section Five. One possibility, whose validity might justify the "circumvention" label, ${ }^{122}$ is that the Court thinks

\footnotetext{
${ }^{119}$ Baker \& Berman, supra note 7, at 461.
}

${ }^{120}$ The models in Parts I and II oversimplify a nuanced interaction within and among the branches. One complication is that the "game" between Congress and the Court is always being played on multiple subject-matter fronts. Thus, the interaction in one area may be partly a function of the dynamic in others. In this situation, the predictive power of any one subject-matter model is reduced. To avoid this problem, the modeler would have to show an absence of significant spillover effects from the other games being played by Congress and the Court.

One could complicate the foregoing models by including more possible moves (e.g., different degrees of judicial responses) or additional players - e.g., different groups within Congress, see supra note 43, or the public. The Justices are not indifferent to public acceptance of their decisions, at least over the long run. See, e.g. Neil S. Siegel, Umpires At Bat: On Integration and Legitimation (unpublished manuscript on file with author). And of course members of Congress worry about reelection. Because the public makes no moves in the previous games, the models obviously simplify reality. This simplification, however, makes sense in light of the context. While it is always difficult to predict how possible public reaction affects the Court, such predictions are particularly perilous in the area of federalism, where the public has little understanding and interest. If the Court were to revisit a popular spending program, such as provisions of the Civil Rights Act of 1964, public reaction might play a role.

In light of my omission of the public as a player, the analysis is best viewed as addressing the many situations in which the choices of Congress and the Court are unlikely to cause a strong public reaction. Assuming that the federalism cases decided by the Roberts Court result in public reactions similar to those generated by the Rehnquist Court, possible public reaction is unlikely to matter much.

11.

${ }^{121}$ For Professors Baker and Berman's discussion of this issue, see Baker \& Berman, supra note 7, at 507-

${ }^{122}$ But see supra note 29 (discussing the problematic nature of the term "circumvention"). 
Congress should not seek to regulate the activity in question using any of its constitutional sources of legislative authority. The Court, according to this view, conceives the activity as concerning a matter that the Constitution leaves to the states. I denote this position "substance federalism."

A second possibility, which I call "form federalism," is that the Court believes a given regulation exceeds a particular congressional power, but would have no objection if Congress sought to accomplish the same goal through a different, legitimate source of authority. The Court, on this view, believes that different constitutional "hooks" for federal legislation implicate distinct substantive values. A form federalist Court would conceive many uses of the conditional spending power as permissible substitutions, not circumvention — as using a power appropriately as opposed to unconstitutionally.

A third possibility is what I call "form-plus-pique federalism," which refers to a Court that would be provoked by use of the Spending Clause after analogous use of the Commerce Clause or Section Five had been struck down, though the Court would not have been concerned about such use of the Spending Clause had no previous Commerce Clause or Section Five decision been rendered. An example would be a gun-free school zones spending-power statute without a jurisdictional element passed after Lopez came down, as opposed to before. ${ }^{123}$ Such a

${ }^{123}$ See infra note 125 and accompanying text (discussing a post-Lopez proposal for such a statute). While claims about substance federalism and form federalism are empirically falsifiable based on how the Court decides cases, form plus pique is different because there is no sure way to know if the Court is expressing a commitment to federalism, pique, or both. If pique exists, it would manifest itself in the Court's choosing the substance federalist option rather than the form federalist alternative. When the Court decides that a matter exceeds the scope of a particular power, it is likely not focusing on which of these two models it has in mind. This issue arises when Congress tries to accomplish the same regulatory objective through another power. Then the Court must decide if it is substance federalist or form federalist. If pique exists, it may cause the Court to render the substance federalist decision. I therefore conceive pique as a reason that the Court would choose the substance federalist outcome. 
Court does not care about the substance of federalism per se in spending-power cases so much as it does not want to be "shown up" by a Congress that questions its authority. ${ }^{124}$

I consider aspects of these positions in reverse order. It is possible that the pique phenomenon could affect the reactions of certain Justices to instances of conditional spending. Thus, the factual nexus between the strings attached to particular federal grants and previous Supreme Court decisions may be significant. For example, had Congress acted on President Clinton's idea to condition federal education funds on the enactment by states of gun-free school zone laws imposing the same requirements as the federal law struck down in Lopez, ${ }^{125}$ the Court's hackles might have been raised. So too if Congress had responded to Morrison by conditioning federal law-enforcement funds on the enactment of state statutes providing private civil actions for victims of gender-motivated violence. ${ }^{126}$

An interesting case arises in the New York-type scenario - that is, when the Court appears to invite Congress to pursue the same regulatory objective through the spending power instead of the Commerce Clause. ${ }^{127}$ As a general matter, Congress may sensibly proceed as if it is dealing with a form federalist Court in such situations by taking the Court at its word — and to

${ }^{124}$ Another possible type is "little or no judicially enforced federalism." I do not focus on this possibility because it will garner four, and only four, votes in the near term (i.e., Justices Stevens, Souter, Ginsburg, and Breyer). Note, however, one implication of the current numbers: all it would take for the Court to sustain Dole even in the face of congressional "circumvention" of previous federalism holdings is for one form federalist Justice to join the four nationalists. It is not clear, however, who this one Justice would be. 1995, at A1.

${ }^{125}$ See Todd S. Purdum, Clinton Seeks Way to Retain Gun Ban in School Zones, N.Y. TimES, Apr. 30,

${ }^{126}$ There is some historical support for this view. In Bailey v. Drexel Furniture Co., 259 U.S. 20 (1922), eight Justices voted to strike down the federal Child Labor Tax Act, Pub. L. No. 65-254, 40 Stat. 1138 (1919), despite several recent precedents strongly indicating its validity. The Court invalidated the law because it was a response to the Court's decision in Hammer v. Dagenhart, 247 U.S. 251 (1918), which had held beyond the commerce power a federal statute barring interstate shipment of goods produced by child labor. The Bailey Court candidly explained that "a court must be blind not to see that the so-called tax is imposed to stop the employment of children within the age limits prescribed. Its prohibitory and regulatory effect and purpose are palpable. All others can see and understand this. How can we properly shut our minds to it?" 259 U.S. at 37.

${ }^{127}$ See supra notes 57-60 and accompanying text. 
state that it is doing so in the statute itself. ${ }^{128}$ Some measure of congressional caution is still warranted because the Justices do not always say exactly what they mean or mean exactly what they say. ${ }^{129}$ A non-zero probability exists that certain Justices might smell "circumvention" if a Spending Clause statute were enacted in response to a decision such as New York. But most of the data from the case law suggest that Congress should deem it permissible to pursue important regulatory objectives through the spending power when the Court has indicated that such a course of action would amount to a permissible substitution, not circumvention.

In defense of the substance federalism position, one might train one's attention on the views of the Justices regarding the extent to which specific conditional grants compromise federalism values - the substance of federalism — which the Court has sought to protect in past decisions. Justice Kennedy has recorded such an observation:

[T] he Spending Clause, if wielded without concern for the federal balance, has the potential to obliterate distinctions between national and local spheres of interest and power by permitting the Federal Government to set policy in the most sensitive areas of traditional state concern, areas which otherwise would lie outside its reach. ${ }^{130}$

On this view, the Court's opinions in cases such as New York, Lopez, Printz, and Morrison indicate that, according to some Justices, federalism is about substantive values, not formalistic distinctions. Certain congressional uses of the spending power, so the argument runs, would risk

\footnotetext{
${ }^{128}$ In Dagenhart, for example, supra note 126, the Court had not indicated to Congress that alternative means of achieving the same regulatory end would be permissible.

${ }^{129}$ Cf. Seminole Tribe of Fla. v. Fla., 517 U.S. 44, 71, n.14, 73-76 (1996) (underscoring the availability of injunctive actions under the doctrine of Ex parte Young, 209 U.S. 123 (1908), while withdrawing the injunctive alternative in that very case).

${ }^{130}$ See, e.g., Davis v. Monroe County Bd. of Educ., 526 U.S. 629, 654-55 (1999) (Kennedy, J., joined by Rehnquist, C.J., and Scalia and Thomas, JJ., dissenting).
} 
reducing the Court's federalism jurisprudence to the empty edict that Congress impose its will one way but not another, even in "the most sensitive areas of traditional state concern.",131 There is certainly something to this contention in the context of traditional subjects of state regulation, but it encounters several problems. As discussed in Part II, it is difficult to identify what in the Court's view is the essential substance of federalism. It is also difficult to determine, as the Court itself has learned from experience, ${ }^{132}$ how "the most sensitive areas of traditional state concern"133 can be distinguished from the less sensitive areas.

If the Court were to begin restricting the spending power through a substantive conception of impermissible substitutions, moreover, it is not clear how the Justices would be able to cabin coherently, as opposed to arbitrarily, their narrowing of Dole. It is unlikely that the Court would hold unconstitutional all conditions on the receipt of federal funds. And as the Introduction explained, Congress can negotiate many federalism-based restrictions on its regulatory power by using its conditional spending power under Dole. To put the point concretely: It would seem arbitrary for the Court to conclude that the same condition on federal funds is unrelated to the purpose of the funds or unconstitutionally coercive when the subject matter is a sensitive subject of state concern (however defined), but not when some other subject matter is at issue. ${ }^{134}$ The doctrinal requirement of relatedness seems to concern the connection between means and ends — between the condition on federal funds and the purpose of the

${ }^{131} I d$.

132 See Garcia v. San Antonio Metropolitan Transit Authority, 469 U.S. 528 (1985) (overruling National League of Cities v. Usery, 426 U.S. 833 (1976)). The Garcia Court "reject[ed], as unsound in principle and unworkable in practice, a rule of state immunity from federal regulation that turns on a judicial appraisal of whether a particular government function is "traditional' or 'integral."” 469 U.S. at 546-47.

\footnotetext{
${ }^{133} I d$.

${ }^{134}$ See supra note 10 and accompanying text (discussing the relatedness and coercion requirements).
} 
federal spending program. It does not implicate an independent evaluation of the importance of congressional ends from the standpoint of federalism values. Moreover, it is not clear why the same condition on a given number of federal dollars is more coercive when the context is a traditional subject of state concern than when the setting is otherwise. Pre-empirically, it seems reasonable to presume a relatively equal degree of coerciveness across subject-matter categories.

A more likely possibility is that the Court will strengthen across the board (that is, regardless of whether a traditional subject of state concern is implicated) the existing requirement that conditions be clearly stated. ${ }^{135}$ This may happen regardless of whether Congress engages in "circumvention." For example, the Court recently — and unnecessarily — imposed a more restrictive "clear notice" requirement on Spending Clause statutes than the Rehnquist Court had demanded. ${ }^{136}$ Writing for the Court, Justice Alito reasoned that because Congress relied on the spending power in enacting the Individuals with Disabilities Education Act, ${ }^{137}$ the "costs" that may be awarded to prevailing parents in a case arising under the law does not include fees for services rendered by an educational consultant unless Congress provided "clear notice" to the states of this liability. ${ }^{138}$ Justice Ginsburg concurred in the judgment, but she wrote separately to register her "disagreement with the Court's rationale to the extent that it

${ }^{135}$ See supra note 10 and accompanying text (quoting the Dole Court's announcement of the clearstatement requirement). The Court tends to enforce its conception of federalism more by insisting on clear notice than by imposing other doctrinal limits. See, e.g., Edward T. Swaine, The Constitutionality of International Delegations, 104 Colum. L. REV. 1492, 1579 (2004) ("The gap between the nominal scope of federalism doctrine and its judicial enforcement has caused the resort to familiar alternatives, including canons favoring construing statutes so as to avoid infringements on state sovereignty."). Cf. Einer Elhauge, Preference-Eliciting Statutory Default Rules, 102 Colum. L. REV. 2162, 2251-52 (2002) (explaining the Court's reluctance to construe statutes in a way that undermines federalism values in light of its failure "to develop intelligible rules to provide content to the Tenth Amendment").

\footnotetext{
${ }^{136}$ See Arlington Cent. School Dist. Bd. of Educ. v. Murphy, 126 S. Ct. 2455, 2459 (2006).

${ }^{137} 20$ U.S.C. $\$ 1415(\mathrm{i})(3)(\mathrm{B})$.

${ }^{138} I d$. at 2459 .
} 
invokes a 'clear notice' requirement tied to the Spending Clause."139 Chief Justice Roberts and Justices Scalia, Kennedy, and Thomas joined Justice Alito's majority opinion. The opinion of the Court gave no indication that a revisitation of Dole's coercion or relatedness requirements was in the offing. Instead, the Court reaffirmed that "Congress has broad power to set the terms on which it disburses federal money to the States, see, e.g., South Dakota v. Dole."140

The line between uses of the conditional spending power that the Court would allow and those that it would reject as impermissible substitutions is presently unclear. This is because it is unclear what kind of Court the current Court is: substance federalist, form federalist, or form plus pique. We do not yet have sufficient data in the form of relevant opinions. Congress, then, needs to learn from further signaling by the Court. The optimal congressional strategy depends upon the extent to which five Justices care most about federalist substantive values, the form of congressional action, and what I call form plus pique. ${ }^{141}$ Which game Congress is currently playing with the Court turns on how one counts to five. ${ }^{142}$ In other words, the identity of the game turns on the identity of the median Justice. ${ }^{143}$

${ }^{139} I d$. at 2465 (Ginsburg, J., concurring in part and concurring in judgment).

${ }^{140} I d$. at 2459. There is also no indication that the Court is likely to adopt Professor Baker's distinction between "regulatory spending" and "reimbursement spending." See Lynn A. Baker, Conditional Federal Spending after Lopez, 95 COLUM. L. REV. 1911, 1962-63 (1995).

${ }^{141}$ Of course, any given Justice may care about more than one of these considerations, so that the differences in particular cases may be more a matter of degree than kind. For example, a basically form federalist Justice may react with pique if Congress goes out of its way to antagonize the Court. Alternatively, a basically substance federalist Justice may still think that the form of congressional action makes some difference to the constitutional inquiry.

${ }^{142}$ The situation could be modeled as a signaling game, which requires analysis of player moves and player beliefs about the signaling player's “type." See OSBORNE \& RUBINSTEIN, supra note 41, at 237-38. First the Court hands down a decision, then Congress draws an inference about the Court's type based on the language in the opinion and acts accordingly, and finally the Court responds by sustaining or trimming Dole. Conceiving the interaction as a signaling game may suggest that judicial language matters, but not just because it explains the Court's rationale. The language, as opposed to the holding or judgment, may also signal certain deeply held concerns of the Court. This possibility informs my conjecture that the constitutional scope of the spending power was on the minds of at least some of the Justices in Cutter. See supra notes 85-88 and accompanying text. Because of the signaling power of judicial language, the Court's words could scare away Congress or invite a response. The 
It is unlikely that Justices Stevens, Souter, Ginsburg, or Breyer would vote to narrow

Dole under any circumstances because of the implications for national power discussed

throughout this Article. It also seems clear from cases such as Sabri and Cutter that Justice

Thomas would vote to trim or overrule Dole even if "unprovoked" by Congress.

I surmise that Chief Justice Rehnquist, Dole's author, has not been replaced by a

substance federalist. ${ }^{144}$ We do not yet know a lot about the relevant views of Chief Justice

Roberts. $^{145}$ Though the data are too sparse to support firm conclusions, it appears most likely

that his commitments are similar to those of Chief Justice Rehnquist. Chief Justice Roberts has

Court might also be vague intentionally — it might send a mixed signal and generate a pooling equilibrium, see OSBORNE \& RUBINSTEIN, supra note 41, at 237-38 - because it wants to keep Congress somewhat in the dark. Commentators may read the tea leaves differently in part because the Court has sent mixed signals.

Perhaps the Court does not want to trigger a congressional response that would require it to revisit Dole because of the legitimacy costs that can accompany disrespect for precedent and the doctrinal complications that would have to be negotiated. The Justices may also worry that a Court that disrespects precedent may encourage others, including future Courts, to do the same. Accordingly, Justices committed to federalism in a real but limited way may use aggressive language to signal a robust commitment to federalism. Whether this degree of stated commitment is credible depends upon the Court's or the signaling Justice's type. Thus, ambiguous language in some opinions may reflect not just an attempt to secure a majority, but also an effort to deter a congressional "override." Through careful drafting, the Court can seek to vindicate the degree of its commitment to federalism without having to revisit Dole or to reveal its disinclination to do so. It may write that federalism means X and Congress is constrained when it is not prepared to vindicate federalism values to such a robust extent. Congress must then decide whether to call the Court's bluff.

${ }^{143}$ See supra note 49 (observing that the views of at least five Justices are captured by the view of the median Justice when the various views line up along a single dimension). My four typologies — no judicially enforced federalism, form federalism, form-plus-pique federalism, and substance federalism - do seem to align along a single ideological spectrum in the order just mentioned from left to right:

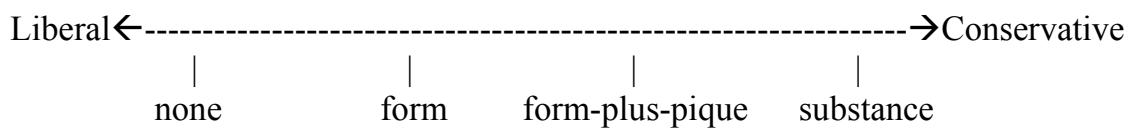

As discussed in the text, what is presently unclear is both the identity of the median Justice and whether he is a form federalist or something further to the right.

${ }^{144}$ If this preliminary assessment of Chief Justice Roberts turns out to be incorrect, the views of Justices Scalia, Kennedy, and Alito become especially important.

${ }^{145}$ It may be somewhat revealing, however, that Chief Justice Roberts rejected federalism-based arguments in the Oregon assisted-suicide case. See Gonzales v. Oregon, 126 S. Ct. 904, 926 (2006) (Scalia, J., joined by Roberts, C.J., and Thomas, J., dissenting). Then again, so did Justice Thomas. See id. The Court did not issue a constitutional holding in this case. 
revealed some desire to restrict congressional authority under the Commerce Clause while endorsing broad use of the conditional spending power. ${ }^{146}$

As noted in the Introduction, Chief Justice Roberts repeatedly suggested at oral argument in Rumsfeld v. FAIR that law schools are free to exclude military recruiters by turning down as much as $\$ 100$ million in federal funding. ${ }^{147}$ In his opinion for the Court, moreover, he wrote that "universities are free to decline the federal funds" if they do not wish to comply with the Solomon Amendment. ${ }^{148}$ His words do not bode well for commentators who would like to see the Court put some teeth into Dole's noncoercion requirement. ${ }^{149}$ To be sure, the Chief Justice may not end up being consistent across contexts regarding coercion questions, and he may perceive a principled difference between limits on conditional spending because of First Amendment unconstitutional-conditions doctrine and limits on conditional spending because of federalism concerns. But his repeated, provocative statements at oral argument in FAIR do not hint at such nuanced distinctions, nor does his opinion for the Court. Nor did the Justice for whom he clerked (Rehnquist) believe that such distinctions made a relevant difference in conditional spending cases.

\footnotetext{
146 Compare Rancho Viejo, LLC v. Norton, 334 F.3d 1158 (DC Cir. 2003) (Roberts, J.) (dissenting from denial of reh'g en banc) (disagreeing with the analysis supporting his court's conclusion that an Endangered Species Act regulation governing the treatment of a wildlife species was within the scope of the commerce power), with Barbour v. WMATA, 374 F.3d 1161 (DC Cir. 2004) (rejecting several sovereign immunity arguments, including that the District of Columbia could not be subject to suit under Section 504 of the Rehabilitation Act because the federal funds it received were not sufficiently related to the waiver of sovereign immunity required by the statute).

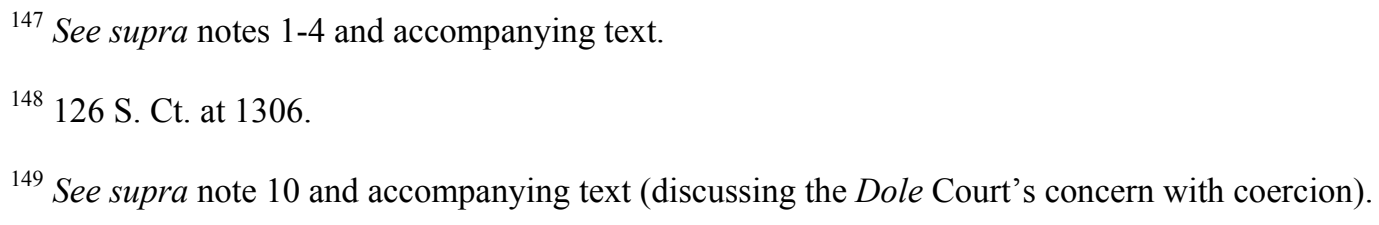


Justice Alito's views on the spending power are presently uncertain. But in light of his apparently strong commitment to federalism, ${ }^{150}$ it seems unlikely that he will turn out to be a form federalist, as opposed to a form-plus-pique federalist or a substance federalist. ${ }^{151}$

Turning to Justices Scalia and Kennedy, the available evidence suggests that as a general matter, they are at most form-plus-pique federalists regarding the Spending Clause. Justice Scalia joined the Court's opinion in Dole (Justice Kennedy was not yet on the Court) ${ }^{152}$ both signed onto Justice O'Connor's invocation of Dole in New York $;{ }^{153}$ neither used Guillen as a vehicle to announce a desire to revisit Dole $;{ }^{154}$ and neither joined Justice Thomas' effort to limit the scope of the Spending Clause in Sabri and Cutter. ${ }^{155}$ To be sure, Justice Kennedy did send a substance-federalism signal in his Davis dissent and a mixed message in his opinion for the Court in Alden, and Justice Scalia joined both opinions. ${ }^{156}$ But their overall voting behavior is different from that of a true substance federalist like Justice Thomas. ${ }^{157}$ Justices Scalia and

${ }^{150}$ See, e.g., Rybar, 103 F.3d at 294 (Alito, J., dissenting) (“As Lopez reminded us, the 'constitutionally mandated division of authority [between the federal government and the states] 'was adopted by the Framers to ensure protection of our fundamental liberties.' ' And even today, the normative case for federalism remains strong. Out of respect for this vital element, we should require at least some empirical support before we sustain a novel law that effects 'a significant change in the sensitive relation between federal and state criminal jurisdiction."' (internal citations omitted)). For the question presented in Rybar, see supra note 98.

${ }^{151}$ See supra notes 136-140 (discussing Justice Alito's imposition of a robust "clear notice" requirement in a recent opinion for the Court.

${ }^{152}$ Cf. Linda Greenhouse, The Rehnquist Court and Its Imperiled States' Rights Legacy, NEW YoRK TIMES, June 12, 2005, §4, at 3 (noting the weakness of Justice Scalia's commitment to federalism relative to the other conservatives on the Court).

${ }^{153}$ See supra text accompanying note 57.

${ }^{154}$ See supra notes 63-67 and accompanying text.

${ }^{155}$ See supra notes 72 and 88 and accompanying text.

${ }^{156}$ See supra notes 7, 130-131 and text accompanying note 62.

${ }^{157}$ In addition to Sabri and Cutter, Raich highlights differences on federalism questions between Justices Scalia and Kennedy on the one hand and Justice Thomas on the other. See supra note 94 and accompanying text. 
Kennedy are as committed to robust federal power as they are to federalism. ${ }^{158}$ One senses from the opinions they joined in Cutter, Sabri, and Guillen that they are not inclined to cut Dole back. At the same time, they are firmly committed to judicial supremacy and might be provoked by a headstrong Congress. ${ }^{159}$

Based on the foregoing analysis, I read the current situation this way: (1) Fewer than five votes exist for the "little or no judicially enforced federalism" view; (2) fewer than five votes exist for the "substance federalism" commitment, which would conceive the Spending and Commerce Clauses as implicating the same federalism concerns; (3) fewer than five votes exist for the form federalism position; and (4) it is unclear how many Justices are appropriately characterized as form-plus-pique jurists. Because of (4), it is unclear (a) whether five votes exist for a combination of "no judicially enforced federalism" and form federalism, or (b) whether and when - five votes exist for a combination of substance federalism and form plus pique. ${ }^{160}$

If scenario (a) more accurately characterizes the current Court (Justices Stevens, Souter, Ginsburg, and Breyer plus one other), then the Go-Bananas-Over-Dole game from Part II approximates the current strategic interaction between Congress and the Court. If scenario (b)

${ }^{158}$ This is hardly to suggest, however, that Justices Scalia and Kennedy view federalism questions the same way regardless of context. Compare, e.g., Rapanos v. United States, 126 S. Ct. 2208, 2212, 2224 (2006) (plurality opinion of Scalia, J.), with id. at 2249 (Kennedy, J., concurring in judgment).

${ }^{159}$ See, e.g., City of Boerne, 521 U.S. at 535-36 ("When the political branches of the Government act against the background of a judicial interpretation of the Constitution already issued, it must be understood that in later cases and controversies the Court will treat its precedents with the respect due them under settled principles, including stare decisis, and contrary expectations must be disappointed."). Four times Justice Kennedy's majority opinion invoked Marbury v. Madison, 5 U.S. (1 Cranch) 137 (1803). See 521 U.S. at 516, 529, 536, 536. See also Robert C. Post \& Reva B. Siegel, Equal Protection By Law: Federal Antidiscrimination Legislation After Morrison and Kimel, 110 YALE L.J. 441, 454 (2000) ("In Boerne, the Court was plainly provoked by Congress's openly expressed purpose to nullify the Court's own interpretation of the First Amendment in Smith.... RFRA posed a direct challenge to the Court's interpretation of the Free Exercise Clause, a challenge that the Court was determined to resist ...." (footnote omitted)). For discussion of City of Boerne and Smith, see supra notes 82-83.

${ }^{160}$ Of course, this analysis is oversimplified. Different cases might trigger different "type" responses from the same Justice. The context can matter greatly. But Congress must proceed one way or another, and its conduct is most likely to be sound when it is based on informed speculations and generalizations, not ignorance of the strategic context in which it operates. 
constitutes the better speculation (Chief Justice Roberts and Justices Scalia, Kennedy, Thomas, and Alito), then the Baker-Berman Dole Game from Part I has great force.

The uncertainty is attributable to serious questions about the robustness of the pique phenomenon. There may be something to it, but there is probably less than might at first appear. The language and voting behavior in City of Boerne do seem to reflect some degree of pique. ${ }^{161}$ The Court, however, displayed no sign of pique in Cutter,${ }^{162}$ even though RLUIPA was a response not just to Employment Division v. Smith, but to City of Boerne as well ${ }^{163}$ — and the Court in City of Boerne did not invite a spending-power response. The City of Boerne Court viewed the RFRA Congress as using Section Five effectively to overrule Smith and to impose its own, more expansive understanding of the Free Exercise Clause. But maybe the Cutter Court implicitly perceived the RLUIPA Congress as merely substituting an inappropriate constitutional "hook" for a permissible one by conditioning federal money on the agreement of recipients to abide by Congress' statutory commitment to free exercise in certain settings. It may matter that Congress used the spending power, not Section Five, in enacting RLUIPA. In contrast to Section Five legislation, the Justices may not view a Spending Clause statute enacted "in direct response" $" 164$ to a Supreme Court decision as triggering weighty concerns about "the preservation of judicial control over the ultimate meaning of the Constitution."165

\footnotetext{
${ }^{161}$ See supra note 159 and accompanying text.

${ }^{162}$ See supra notes 80-88 and accompanying text (discussing RLUIPA and Cutter).

${ }^{163}$ See supra text accompanying note 82 (describing RLUIPA as the "child of RFRA").

${ }^{164}$ City of Boerne, 521 U.S. at 512.

${ }^{165}$ Post \& Siegel, supra note 159, at 454.
} 
The Court's decision in Gonzales v. O Centro Espirita Beneficente Uniao Do Vegetal ${ }^{166}$ further undermines the potential relevance of pique. The Court there unanimously allowed RFRA to be applied to the federal government, notwithstanding the Court's decision in Smith, suggesting that City of Boerne was less about pique than about Section Five, which was not implicated in O Ocentro. The $O$ Centro Court noted only that "Congress responded" to Smith by enacting RFRA, and that the Court in City of Boerne "held the application [of RFRA] to States to be beyond congressional authority under Section Five of the 14th Amendment." ${ }^{167}$ Section Five statutes may be particularly threatening to Justices who believe that Congress does not possess independent authority to act on its own interpretation of the Constitution. ${ }^{168}$

It is also possible that there is path dependence to pique. Perhaps certain Justices would vote or write differently in City of Boerne if they had to do it over again, and they do not want to make the same mistake going forward. ${ }^{169}$ We know now that Justices Stevens, Souter, Ginsburg, and Breyer object strenuously to the Court's subsequent reliance on the separation-of-powers

166126 S. Ct. 1211 (2006) (holding that lower courts did not err in determining that the federal government had failed to demonstrate, as it must under RFRA, a compelling interest in enforcing a federal statutory ban on sacramental use of hoasca, a hallucinogenic tea).

${ }^{167} I d$. at $1216-17$ \& n. 1 .

${ }^{168}$ See, e.g., Post, supra note 31, at 47 n. 217 ("[T] he Court perceives the exercise of Section 5 power as a threat to its interpretive monopoly, whereas it does not perceive the exercise of Article I powers as threatening in the same way. This is not because Congress interprets the Constitution any less in exercising its Article I powers, but because the Court believes that congressional interpretation of Fourteenth Amendment rights is closer to the kind of constitutional interpretation routinely practiced by courts." (internal citation omitted)). It was not always this way. Compare Katzenbach v. Morgan, 384 U.S. 641 (1966) (upholding Congress' Section 5 power to ban literacy tests), with Lassiter v. Northampton County Bd. Of Elections, 360 U.S. 45 (1959) (rejecting an equal protection challenge to a state law that conditioned voting eligibility on meeting a literacy requirement).

${ }^{169}$ Justices Stevens and Ginsburg joined the Court's opinion restricting the Section Five power a year after the Court in Seminole Tribe severely limited the power of Congress to abrogate state sovereign immunity outside the context of Section Five. See supra note 13 and accompanying text. Moreover, Justices Souter and Breyer dissented because of free exercise concerns; neither focused on the Court's Section 5 analysis. See 521 U.S. at 565 (Souter, J., dissenting); id. at 566 (Breyer, J., dissenting). 
rationale of City of Boerne in the service of federalism. ${ }^{170}$ In any event, one should exercise great caution before routinely attributing pique to Justices, as the phenomenon may suggest a degree of self-importance and even irrationality that is inappropriate and insulting.

All things considered, the foregoing analysis suggests that Congress should neither accept invitations to "go bananas" over Dole nor be cowed by dire warnings to "get off the Dole." Instead, Congress should follow a middle legislative path, though one closer to the approach espoused by critics of the Court. Congress should proceed with some, but not great, caution in conditioning federal funds under Dole. It should feel free to operate extensively — but sensibly ${ }^{171}$ - within the large universe of interventions that do not implicate the subject matter of previous Court decisions. Congress should also feel free to operate with the small universe of interventions that $d o$ implicate the subject matter of past rulings if the Court in these decisions sincerely (as best one can tell) invited further action pursuant to the Spending Clause, or if Congress deems its interest in legislating pursuant to the spending power important enough that it is worth taking the modest risk of causing the Court to revisit Dole. ${ }^{172}$

${ }^{170}$ See supra note 14 (collecting cases); see generally Post \& Siegel, supra note 159.

${ }^{171}$ Because only the most brazen, "in-your-face" action by Congress would prompt the Court to revisit an issue that it would rather avoid, and because the present indications are that the Court would prefer not to revisit Dole, the range over which the game-theoretic "provocation" principle might operate is very narrow, and no action is likely to materialize in this range in any event. If the Court revisits Dole, it most likely will use as a vehicle not a substitution statute, but one in which Congress put a Dole criterion to the test without having reacted to a decision by the Court. Congress would therefore be well advised to assess the expected costs and benefits before enacting laws that put pressure on the Dole requirements to an unprecedented extent.

${ }^{172}$ One potentially non-obvious implication of the pique phenomenon is that Congress should employ the Spending Clause as a weapon of first resort when the alternative is a constitutionally suspect use of the Commerce Clause or Section Five. This strategic interaction could be modeled by adding a stage before the first round of the games in Parts I and II. In the initial round of this four-stage game, Congress would choose between regulating (i.e., relying on the Commerce Clause or Section Five) and using the conditional spending power. If Congress elected to regulate, then the game in Parts I and II would unfold. If Congress chose instead to use the conditional spending power, then the game would end. 
The last part of the above formulation is critical. One must accord appropriate weight to the significance of the congressional interests in particular cases. A modest degree of legislative caution is warranted in light of the possibility that aggressive use of the spending power could trigger a reaction by the Court to limit the spending power. But to the extent that its members are able to come together and function as a rational actor, Congress still should consider the importance of the goal that it wants to achieve by enacting a particular spending power statute. The expected benefits of a particular spending law must be considered alongside the expected costs; strategic behavior by Congress must follow from a balancing of the expected gains (the importance of the bill under consideration) against the risks (the possibility of provoking the Court to cut Dole back). Such a cost-benefit tradeoff will exist as long as the probability of provocation is less than 1 . And such provocation is far from certain if Congress legislates aggressively pursuant to the Spending Clause in a given instance. ${ }^{173}$

\section{CONCLUSION}

When one accounts for the breadth of the universe of potential spending-power interventions that do not implicate the subject matter of previous Court decisions, the narrowness

\footnotetext{
${ }^{173}$ I have assumed throughout that members of Congress care about the extent to which the Court constrains use of the conditional spending power. To the extent that this assumption is inaccurate — perhaps, as has been suggested to me, because Congress can impose implicit conditions that cannot be policed judicially by choosing to fund or not to fund certain activities based simply upon what it sees states doing or not doing in the world - the strategic situation changes profoundly. Indeed, if Congress is indifferent to the Court's decisions, no strategic interaction exists. Most commentators, however, believe otherwise regardless of their ideological commitments. And the recent Senate confirmation hearings for Chief Justice Roberts and Justice Alito suggest that members of Congress care intensely about the Court's federalism decisions as a general matter. When the Court invalidates a federal law in the name of federalism, the people in Congress who supported the law tend to react strongly to the bad news from across the street. See, e.g., Confirmation Hearing on the Nomination of John G. Roberts, Jr. to be Chief Justice of the United States Before the S. Comm. on the Judiciary, 109th Cong. 299 (2005) ("I am going to move now to the confrontation between Congress and the Court, and what I consider to be denigrating comments about the Congress.") (statement of Senator Specter). See also id. at 25 (statement of Senator Dewine); id. at 225, 349 (statements of Senator Feinstein); id. at 440 (statement of Senator Schumer). These statements indicate that pique may also operate on the congressional side of the interaction.
} 
of the category of possible interventions that do implicate this subject matter, ${ }^{174}$ the availability of the category in which the Court invites a spending-power substitute, the reasons to doubt the robustness of the pique phenomenon, and the situation-specific weight of the congressional interest in using the Spending Clause, it becomes apparent that warnings to "get off the Dole" have force in very few situations. I do not conclude that Professors Baker and Berman's notion of "circumvention" has no relevance, but I do suggest that it is unlikely to play a causal role if the Court elects to revisit Dole in the years ahead.

While I conclude that Professors Baker and Berman's "cautionary note" $" 175$ is overly cautious, and while the foregoing use of game theory illustrates that they are not the only ones in this debate who attend to strategic considerations, I endorse their call for greater attention to the strategic dimension of constitutional law. Commentators who are masters of doctrinal constitutional scholarship often do not emphasize the strategic point of view. ${ }^{176}$ To be sure, traditional legal analysis is most valuable as a general matter in constitutional law; indeed, it is the coin of the legal realm. In nonstrategic settings, doctrinal arguments identify the various options as well as the consequences of these options. The outcomes of cases often turn on such considerations. Even in strategic settings, moreover, the same may be true. Strategic analysis cannot identify the views of the Justices regarding whether and where a line exists between "circumvention" and permissible substitutions, nor can strategic arguments identify the various ways in which the Court might tighten Dole's generous requirements.

\footnotetext{
${ }^{174}$ The claim in the text about the relative breadth of the two categories follows from the reality that the Rehnquist Court invalidated only a handful of federal laws on federalism grounds. Naturally, difficult questions of categorization will arise at the margins. Whether a particular use of the conditional spending power falls into one category or the other may depend on how broadly one reads the Court's holdings in, for example, Lopez, Morrison, and Raich.

${ }^{175}$ See supra note 23.

${ }^{176}$ See, e.g., Choper, supra note 7.
} 
In strategic settings, however, static doctrinal analysis may not be enough. Detailing all of the ways that Congress can get out from under one set of decisions by relying on another is insufficient. One must also examine the likelihood that the Court would revisit the latter series of holdings if a majority of Justices concluded that Congress was playing this very game. In other words, one must assess the content of the Court's preference orderings over the various possible outcomes in the strategic interaction at issue.

Beyond the question of Dole's future, therefore, a place exists for strategic analysis of constitutional law. ${ }^{177}$ Constitutional inquiry should not assume that the Court never behaves strategically. It is constituted by nine highly opinionated lawyers whose ideological and methodological commitments cause them to care greatly (though not exclusively) about outcomes, as well as their continuing authority to determine these outcomes. It is therefore important to think about constitutional doctrine as partly a consequence of strategic interactions between Congress and the Court. This point may seem more evident regarding questions of statutory interpretation, where a Court that does not have the last word may seek to avoid a congressional override. But a similar dynamic is at work in more subtle ways in constitutional cases. The Court has the last word absent an amendment, but reality is more complicated. Congress can sometimes react to adverse decisions by using a distinct source of power. And though the Court can take away the various options, such judicial behavior is hardly costless. Congress retains leverage because the Court may not want to bear the legitimacy and rule-of-law costs of overruling precedent, nor may it want to deal with the potentially treacherous doctrinal

\footnotetext{
${ }^{177}$ I have not defended the proposition that Congress or the Court ought to behave strategically. Rather, I have argued that both institutions do behave strategically, at least some of the time, and I have advocated certain instrumental behavior on the part of Congress in order to achieve certain substantive ends. This analysis, therefore, will be a non-starter for those who believe that Congress and the Court should behave in certain ways as a matter of principle regardless of how the other can be expected to react.
} 
consequences of doing so. ${ }^{178}$ If the Court were to trim or abandon Dole, for example, whether analytically coherent doctrine would follow is far from clear.

${ }^{178}$ See supra note 142 (discussing these points). 